Published in final edited form as:

Handb Exp Pharmacol. 2009 ; (193): 399-441. doi:10.1007/978-3-540-89615-9_14.

\title{
Adenosine Receptors and Cancer
}

\author{
P. Fishman \\ Can-Fite BioPharma, 10 Bareket st., Kiryat Matalon, Petach Tikva, 49170, Israel
}

S. Bar-Yehuda, M. Synowitz, J.D. Powell, K.N. Klotz, S. Gessi, and P.A. Borea

\section{Abstract}

The $A_{1}, A_{2 A}, A_{2 B}$ and $A_{3}$ G-protein-coupled cell surface adenosine receptors (ARs) are found to be upregulated in various tumor cells. Activation of the receptors by specific ligands, agonists or antagonists, modulates tumor growth via a range of signaling pathways. The $A_{1} A R$ was found to play a role in preventing the development of glioblastomas. This antitumor effect of the $A_{1} A R$ is mediated via tumor-associated microglial cells. Activation of the $\mathrm{A}_{2 \mathrm{~A}} \mathrm{AR}$ results in inhibition of the immune response to tumors via suppression of $\mathrm{T}$ regulatory cell function and inhibition of natural killer cell cytotoxicity and tumor-specific CD4+/CD8+ activity. Therefore, it is suggested that pharmacological inhibition by specific antagonists may enhance immunotherapeutics in cancer therapy. Activation of the $\mathrm{A}_{2 \mathrm{~B}} \mathrm{AR}$ plays a role in the development of tumors via upregulation of the expression levels of angiogenic factors in microvascular endothelial cells. In contrast, it was evident that activation of $\mathrm{A}_{2 \mathrm{~B}} \mathrm{AR}$ results in inhibition of ERK1/2 phosphorylation and MAP kinase activity, which are involved in tumor cell growth signals. Finally, $A_{3} A R$ was found to be highly expressed in tumor cells and tissues while low expression levels were noted in normal cells or adjacent tissue. Receptor expression in the tumor tissues was directly correlated to disease severity. The high receptor expression in the tumors was attributed to overexpression of $\mathrm{NF}-\mathrm{kB}$, known to act as an $\mathrm{A}_{3} \mathrm{AR}$ transcription factor. Interestingly, high $\mathrm{A}_{3} \mathrm{AR}$ expression levels were found in peripheral blood mononuclear cells (PBMCs) derived from tumor-bearing animals and cancer patients, reflecting receptor status in the tumors. $\mathrm{A}_{3} \mathrm{AR}$ agonists were found to induce tumor growth inhibition, both in vitro and in vivo, via modulation of the Wnt and the NF- $\mathrm{BB}$ signaling pathways. Taken together, $\mathrm{A}_{3} \mathrm{ARs}$ that are abundantly expressed in tumor cells may be targeted by specific $\mathrm{A}_{3} \mathrm{AR}$ agonists, leading to tumor growth inhibition. The unique characteristics of these $\mathrm{A}_{3} \mathrm{AR}$ agonists make them attractive as drug candidates.

\section{Keywords}

$\mathrm{A}_{1}$ adenosine receptor; $\mathrm{A}_{2 \mathrm{~A}}$ adenosine receptor; $\mathrm{A}_{2 \mathrm{~B}}$ adenosine receptor; $\mathrm{A}_{3}$ adenosine receptor; Expression; Tumor growth; Agonists; Antagonists

\section{Introduction}

During the last decade different approaches to treating cancer have been developed based mainly on specific targets that are mostly expressed in tumor but not in normal cells. Furthermore, it is now recognized that individualizing therapy for patients being treated with anticancer agents is an important goal, leading to the prediction of agents that will be efficacious. Adenosine is a purine nucleoside found within the interstitial fluid of tumors at concentrations that are able to modulate tumor growth by interacting with four G-protein-

(C) Springer-Verlag Berlin Heidelberg 2009

pnina@canfite.co.il. 
coupled adenosine receptor (AR) subtypes, designated $A_{1}, A_{2 A}, A_{2 B}$ and $A_{3}$. Selective agonists and antagonists are now available for all four AR subtypes, enabling the examination of these ligands as immunomodulators and anticancer agents. Interestingly, AR levels in various tumor cells are upregulated, a finding which may suggest that the specific AR may serve as a biological marker and as a target for specific ligands leading to cell growth inhibition.

In this chapter, we will present the role played by each of the ARs in mediating tumor growth. Since immune cells such as lymphocytes, macrophages and natural killer (NK) cells were also found to express ARs, their ability to act as cytotoxic cells against tumor cells or to be involved in the antitumor process will be discussed as well. Based on these studies, possible drug candidates (anticancer agents that target ARs) will be presented.

\section{$2 \mathrm{~A}_{1}$ Adenosine Receptor}

The $\mathrm{A}_{1} \mathrm{AR}$ is a G-protein-coupled receptor that mediates many of the physiological effects of adenosine in the brain. The binding of agonists to $\mathrm{A}_{1} \mathrm{AR}$ induces inhibition of adenylate cyclase, leading to a decrease in intracellular cAMP levels or stimulation of phospholipase $\mathrm{C}$ (PLC). The $\mathrm{A}_{1} \mathrm{AR}$ has a high affinity for adeno-sine and has been implicated in both proand anti-inflammatory aspects of disease processes. On the one hand, $\mathrm{A}_{1} \mathrm{AR}$ signaling can promote neutrophil (Salmon and Cronstein 1990) and monocyte activation (Merrill et al. 1997; Salmon et al. 1993); on the other hand, $A_{1}$ AR signaling is involved in antiinflammatory and protective pathways in neuroinflammation and injury (Tsutsui et al. 2004), and in cardiac and renal injury (Liao et al. 2003; Lee et al. 2004a, b). Adenosinemediated anti-inflammatory effects have been studied extensively in macrophages and macrophage cell lines. Adenosine inhibits the production of several proinflammatory cytokines (TNF- $a$, IL-6, and IL-8) by LPS-stimulated macrophages and enhances the release of the anti-inflammatory cytokine IL-10 (Hasko et al. 1996; Le Moine et al. 1996; Sajjadi et al. 1996). Recent studies suggest an anti-inflammatory role for chronic $\mathrm{A}_{1} \mathrm{AR}$ activation by high levels of adenosine in the lung, a surprising and important finding in light of the fact that $\mathrm{A}_{1} \mathrm{AR}$ antagonists are being investigated as a potential treatment for asthma (Sun et al. 2005). In the CNS, the $A_{1} A R$ is highly expressed on microglia/macrophages and neurons (Johnston et al. 2001). In the latter, $\mathrm{A}_{1} \mathrm{AR}$ is coupled to activation of $\mathrm{K}^{+}$channels (Trussell and Jackson 1985) and inhibition of $\mathrm{Ca}^{2+}$ channels (MacDonald et al. 1986), both of which are mechanisms that attenuate neuronal excitability, thereby reducing excitotoxicity, and so adeno-sine can act as a neuroprotective factor. Since $\mathrm{A}_{1} \mathrm{ARs}$ are expressed throughout the brain (Dunwiddie 1985), adenosine has the potential to be involved in different brain pathologies. Although $\mathrm{A}_{1} \mathrm{ARs}$ may play an important role in some physiological functions in the brain (e.g., sleep), $A_{1} A R$-deficient mice show no obvious abnormal behavior, levels of alertness, or appearance of focal neurological deficits, such as seizures (Synowitz et al. 2006). However, upon exposure to pathophysiological conditions like hypoxia, $\mathrm{A}_{1} \mathrm{AR}$-deficient mice show more neuronal damage and have a lower survival rate (Johansson et al. 2001). It was therefore concluded that, in the brain, $\mathrm{A}_{1} \mathrm{ARs}$ are primarily important in mediating effects of adenosine during pathophysiological conditions (Gimenez-Llort et al. 2002; Johansson et al. 2001).

It has recently been reported that the deletion of functional ARs, specifically $\mathrm{A}_{1} \mathrm{AR}$, results in an increase in brain tumor growth, specifically glioblastoma tumor growth (Synowitz et al. 2006). This implies that adenosine acting via $A_{1} A R$ impairs glioblastoma growth. In the context of glioblastoma, $\mathrm{A}_{1} \mathrm{ARs}$ are prominently expressed by the tumor cells and those microglial cells associated with the glioblastoma tumor cells. In an experimental approach using an $\mathrm{A}_{1} \mathrm{AR}$-deficient mouse as a tumor host, the importance of the microglial cells for mediating the $A_{1} A R$ anti-cancer effect is highlighted (Synowitz et al. 2006). In these 
studies, $A_{1}$ AR-deficient mice and their wild-type littermate controls are inoculated with Gl261 tumor cells; thus, with this approach, the $\mathrm{A}_{1} \mathrm{AR}$ is deleted in host cells but not tumor cells. In the control wild-type littermates the microglial cells accumulated at the tumor site, and this accumulation was even more pronounced in the $\mathrm{A}_{1} \mathrm{AR}$-deficient mice. However, tumor volume was significantly greater in $\mathrm{A}_{1} \mathrm{AR}$-deficient mice, suggesting that the microglial cells are the cellular candidates for inhibiting tumor growth. The importance of microglial $A_{1} A R$ is further supported by a brain slice model where inhibition of tumor growth is only observed in the presence of microglial cells. To test the functional effect of $\mathrm{A}_{1} \mathrm{AR}$ activity on glioblastoma growth, an organotypical brain slice model was employed where glioblastoma cells could be injected and ARs could be stimulated or inhibited (Synowitz et al. 2006). Brain slices ( $250 \mu \mathrm{m}$ thick) were cultured for four days and $10^{4}$ GFP-labeled Gl261 tumor cells were injected (suspended in $0.1 \mu \mathrm{L}$ ) into the tissue. The tumor size was evaluated by measuring the area occupied by the fluorescently labeled Gl261 cells. In these studies, adenosine and an $\mathrm{A}_{1} \mathrm{AR}$ agonist, $N^{6}$-cyclopentyladenosine (CPA) significantly decreased tumor size. To determine if this effect of adenosine or activation of $\mathrm{A}_{1}$ ARs depends on the presence of microglia, endogenous microglia were selectively depleted from cultured organotypical brain slices by a $24 \mathrm{~h}$ treatment with clodronate-filled liposomes without affecting other cell types (e.g., neurons, oligodendrocytes, and astrocytes). As reported previously, activated microglia supported glioblastoma tumor growth, resulting in significantly smaller tumors in microglia-depleted slices compared with control slices. This serves as an internal control and thus confirms the observation that the presence of microglial cells per se is tumor promoting (Markovic et al. 2005). There was no significant change in the population of astrocytes or neural progenitor cells. The latter is of particular interest, since it was recently reported that neural progenitor cells are attracted to tumors or to gliomas and attenuate tumor growth (Glass et al. 2005). In these organotypical brain slice studies, tumor cells were injected three days after liposome treatment, and the size of the tumor bulk was evaluated with and without microglia. In theses studies, activation of $\mathrm{A}_{1} \mathrm{ARs}$ with adenosine or CPA resulted in a larger tumor size in brain slices devoid of microglia. Moreover, as expected, the tumor size was greater in brain slices from $\mathrm{A}_{1} \mathrm{AR}$-deficient mice versus their littermate wild-type controls. Furthermore, in these studies, adenosine or CPA had no effect on tumor growth in brain slices from $\mathrm{A}_{1} \mathrm{AR}$ deficient mice. Taken together, the in vivo studies in $\mathrm{A}_{1} \mathrm{AR}$-deficient mice and in vitro studies in organotypical brain slices suggest that CPA and adenosine specifically act on $\mathrm{A}_{1} \mathrm{ARs}$ on microglial cells to reduce tumor size.

The presence of ARs has been previously reported on astrocytoma cells (Prinz and Hanisch 1999) using an $A_{1}$ AR-specific ligand. The presence of ARs on microglia is well established, and some functional implications of their activation have become apparent (Burnstock 2006; Farber and Kettenmann 2006). Cultured rat microglial cells express $A_{2 A} A R s$, since the specific $\mathrm{A}_{2 \mathrm{~A}} \mathrm{AR}$ agonist CGS21680 triggers the expression of $\mathrm{K}^{+}$channels that are linked to microglial activation (Kust et al. 1999). In contrast, $A_{2 A} A R$ stimulation in rat microglia triggers the expression of nerve growth factor and its release, thereby exerting a neuroprotective effect (Heese et al. 1997). Moreover, cyclooxygenase-2 expression in rat microglia is induced by $\mathrm{A}_{2 \mathrm{~A}} \mathrm{ARs}$, resulting in the release of prostaglandin (Fiebich et al. 1996). Hammarberg et al. provided evidence for functional $A_{3} A R s$ in mouse microglial cells while $A_{1}$ ARs were not detected in this study (Hammarberg et al. 2003). However, other studies, based on immunocytochemical data, indicate that microglial cells express $\mathrm{A}_{1}$ ARs and that the presence of tumor cells upregulates the expression of $A_{1} A R s$ in microglia (Synowitz et al. 2006). Moreover, the results of these studies indicate that loss of $A_{1} A R$ leads to an increase of tumor size associated with microglia, which may be due to infiltration and/or proliferation. 
The potential source of extracellular adenosine in the brain is most likely ATP, which is released from presynaptic and postsynaptic terminals of neurons and also from glial cells (Fields and Burnstock 2006). In the extracellular space, adenosine is generated from ATP after dephosphorylation by specific ectoenzymes (e.g., cluster of differentiation 39 (CD39) and cluster of differentiation 73 (CD73)). These ectoenzymes represent a highly organized enzymatic cascade for the regulation of nucleotide-mediated signaling. They control the rate of nucleotide (ATP) degradation and nucleoside (adenosine) formation (Farber et al. 2008; Plesner 1995). Microglial cells express specific ectonucleotidase isoforms, CD39 and CD73, which are not expressed by any other cell type in the brain. Due to this specific expression, both molecules served as microglia-specific markers long before their functional importance was recognized (Braun et al. 2000; Schnitzer 1989; Schoen et al. 1992).

The role of adenosine in microglial proliferation remains controversial. One study reports that adenosine stimulates the proliferation of microglial cells through a mechanism that involves the simultaneous stimulation of $A_{1}$ and $A_{2}$ ARs (Gebicke-Haerter et al. 1996). By contrast, adenosine has been reported to inhibit the proliferation of microglial cells; i.e., phorbol 12-myristate 13-acetate-stimulated microglial proliferation is reduced following treatment with an $\mathrm{A}_{1} \mathrm{AR}$ agonist ( $\mathrm{Si}$ et al. 1996). Moreover, stimulation of the $\mathrm{A}_{1} \mathrm{AR}$ can also cause microglial apoptosis (Ogata and Schubert 1996). Adenosine levels in the extracellular fluid are lower in human glioblastoma tissue than in control tissue, namely 1.5 and $3 \mu \mathrm{M}$, respectively. These values were obtained from human glioblastomas of highgrade malignancy and measured by brain microdialysis coupled to high-performance liquid chromatography (Bianchi et al. 2004). Whether this rather small difference causes the accumulation of microglia close to tumors is speculative.

Recent studies support the idea that ARs and specifically the $\mathrm{A}_{1} \mathrm{AR}$ are good targets for drug development in several diseases that affect the CNS (Fredholm et al. 2005). $\mathrm{A}_{1} \mathrm{AR}$ deficiency aggravates experimental allergic encephalomyelitis (Tsutsui et al. 2004), and it has been repeatedly shown that adenosine can protect tissues against the negative consequences of hypoxia or ischemia (Fredholm 1997), mainly by acting on the $\mathrm{A}_{1} \mathrm{AR}$. Hence, survival after a hypoxic challenge may be reduced if $A_{1} A R s$ are absent or blocked (Johansson et al. 2001). The tissue-protective effect of $A_{1} A R$ has been implicated in experimental paradigms using $\mathrm{A}_{1} \mathrm{AR}$-deficient mice. In a model of renal ischemia and reperfusion injury, $A_{1}$ AR-deficient mice exhibited an increase in production of proinflammatory mediators and showed an increase in renal injury (Lee et al. 2004a, b). Similarly, in a model of experimental allergic encephalomyelitis, $A_{1} A R$ deficiency led to increased neuroinflammation and demyelination and also augmented axonal injury. Both studies concluded that $\mathrm{A}_{1} \mathrm{AR}$ serves anti-inflammatory functions that regulate subsequent tissue damage. Furthermore, metalloproteinase (MMP) 9 and MMP-12 are significantly elevated in $\mathrm{A}_{1}$ AR-deficient mice (Tsutsui et al. 2004). Indeed, MMPs play an important role in glioblastoma progression and, as was recently demonstrated, the expression of MMPs by microglia has an impact on tumor growth (Markovic et al. 2005). Matrix degradation by MMPs is an important prerequisite for glioblastoma invasion (Rao 2003). $A_{1}$ AR activation on microglia/macrophages inhibits not only the production of cytokines like interleukin-1 $\beta$ but also matrix MMPs like MMP-12 (Tsutsui et al. 2004). MMP-12, also known as macrophage elastase, is an MMP that is produced by activated macrophages and preferentially degrades elastin (Werb and Gordon 1975). Hence, inhibition of microglial MMP-12 secretion via activation of $\mathrm{A}_{1} \mathrm{AR}$ could explain the glioblastoma growth inhibition observed in the studies described above. Moreover, the lack of inhibition of MMP-12 by $\mathrm{A}_{1}$ ARs on microglia may explain why there is enhanced accumulation of microglia at the tumor sites in $\mathrm{A}_{1} \mathrm{AR}$-deficient mice along with their tumor-promoting effects (i.e., associated increased tumor size). Adenosine does not appear to directly regulate MMP-12 expression in microglia/macrophages since direct stimulation of cultured macrophages with 
AR agonists did not induce expression of MMP-12 (Sun et al. 2005). It is therefore likely that the removal of $\mathrm{A}_{1} \mathrm{AR}$ signaling leads to enhanced production of mediators in the CNS, which then leads to enhanced MMP-12 production. A likely candidate for this is interleukin (IL)-13, since IL-13 has been shown to be involved in the production of MMP-12 in other model systems (Lanone et al. 2002).

The results from the studies described above suggest that the $A_{1} A R$ plays an antitumorigenic role mediated by microglial cells in the development of glioblastomas. Further research into the mechanisms of how the pathways of $\mathrm{A}_{1} \mathrm{AR}$ signaling modulate glioblastoma development may ultimately lead to treatments to reduce the progression of this disease.

\section{$3 \mathrm{~A}_{2 \mathrm{~A}}$ Adenosine Receptor}

\subsection{The $A_{2 A} A R$ : Protector of Host Tissue, Protector of Tumors}

The seminal observations of Ohta and Sitkovsky (2001) clearly established a role for the $\mathrm{A}_{2 \mathrm{~A}} \mathrm{AR}$ in protecting host tissue from destruction by overexuberant immune responses. Considering that the tumor microenvironment contains relatively high levels of extracellular adenosine, data is emerging to support the hypothesis that tumor-derived adenosine is one mechanism by which tumors evade immune destruction (Blay et al. 1997; Ohta et al. 2006). In this section, we will discuss the role of adenosine in thwarting antitumor immunity and the potential pharmacologic interventions on the horizon that may serve to overcome this hurdle to immunotherapy.

\subsection{Tumors Evade the Immune System by Inhibiting Immune Cell Function}

The ability of the immune system to specifically recognize antigen makes it a potentially powerful tool in terms of developing modalities to treat cancer. However, in spite of many recent advances in understanding of and ability to identify tumor antigens, immunotherapy is clearly yet to live up to its full potential. In part, this is because tumors evade immune destruction by inhibiting tumor-specific immune cells (Pardoll 2002). For example, while a particular tumor may express a very unique and readily recognized tumor antigen, if this antigen is presented by resting or nonprofessional antigen-presenting cells (APCs), T-cell receptor (TCR) recognition will not lead to the destruction of the tumor but rather the inactivation of the tumor-specific $\mathrm{T}$ cell.

In this context, it is not the inability of $\mathrm{T}$ cells to recognize the tumor that is hampering cancer immunotherapy, but rather a lack of antigen-induced immune activation. That is, tumors readily express and $\mathrm{T}$ cells readily recognize tumor antigens (Overwijk and Restifo 2001). The problem is that T-cell recognition of the tumor does not lead to tumor destruction but rather to T-cell tolerance. In this regard, the tumor microenvironment is fraught with humors and cells that facilitate the ability of tumors to evade immune destruction (Drake et al. 2006). For example, the cytokines IL-10 and transforming growth factor $\beta$ (TGF- $\beta$ ) in the tumor microenvironment can both directly inhibit T-cell function as well as promote the induction of regulatory $\mathrm{T}$ cells and tolerogenic APCs. Likewise, tumors can express coinhibitory ligands such as B7-H1 and B7-H4. These in turn engage molecules on the surfaces of T cells such as PD-1 that serve to inhibit T-cell function. In this context, it is becoming clear why tumor vaccines have failed to live up to their potential so far (Pardoll 2002). Vaccine regimens which have focused on trying to enhance tumor-specific $\mathrm{T}$ cells by utilizing viral vectors, DNA vaccines, cytokine-secreting cells and antigen-pulsed dendritic cells have all shown promise in animal models and even some clinical trials. Put simply, in spite of the ability of such approaches to generate activated tumor antigen-specific $\mathrm{T}$ cells, the efficacy of such cells is thwarted by the multiple immunologic checkpoints exploited by the tumor. With this in mind, current immunotherapeutic strategies are focused on blocking 
these checkpoints. In this regard, blocking antibodies against cytotoxic T lymphocyteassociated antigen 4 (CTLA-4 (a negative regulator of T-cell activation) has shown great promise in a number of animal models (Egen et al. 2002). Likewise, blocking anti-PD-1 antibodies are also currently being tested in order to enhance tumor immunotherapy (Blank and Mackensen 2007).

\subsection{The $A_{2 A} A R$ Negatively Regulates Immune Responses}

The ability of adenosine to inhibit immune function has been known for some time (Linden 2001). However, in light of the fact that there are four known AR subtypes, the critical, nonredundant role of the $\mathrm{A}_{2 \mathrm{~A}} \mathrm{AR}$ in mediating adenosine-induced anti-inflammatory responses was somewhat surprising. In a series of experiments, Sitkovsky's group demonstrated that normally nonlethal, self-limiting inflammation in wild-type (Wt) mice led to excessive inflammation and death in $\mathrm{A}_{2 \mathrm{~A}} \mathrm{AR}$-null mice (Ohta and Sitkovsky 2001). These observations and additional studies led to a model whereby tissue damage resulting from inflammation leads to the release of extracellular adenosine, which then acts to quell the inflammatory response by acting on bone marrow-derived immune cells. Indeed, $\mathrm{A}_{2 \mathrm{~A}} \mathrm{AR}$ signaling on immune cells such as macrophages, $T$ cells and dendritic cells has been shown to limit effector cell function (Erdmann et al. 2005; Huang et al. 1997; Khoa et al. 2001; Lappas et al. 2005; Naganuma et al. 2006; Panther et al. 2001; Schnurr et al. 2004). The existence of this negative feedback loop has led Sitkovsky to propose that, from an immunologic prospective, adenosine should be viewed as a metabokine that acts as an inhibitory second signal (Sitkovsky and Ohta 2005). For example, during an infection, pathogen-associated molecular patterns (PAMPs) along with host-derived uric acid, high mobility group (HMG1b) and hyaluronan (HA) would promote activating "danger signals" (Scheibner et al. 2006; Shi et al. 2003; Williams and Ireland 2008). As the inflammation progresses, the pathogen will be eliminated and the concentration of the potent immuneactivating PAMPS will markedly decrease. In this setting, the inhibitory affects of adenosine released by damaged tissue will dominate to protect the tissue from further destruction by overacting immune responses.

Adenosine acting via the $\mathrm{A}_{2 \mathrm{~A}} \mathrm{AR}$ has the ability to influence inflammation by inhibiting proinflammatory cytokine secretion, $\mathrm{C} 2$ activation, macrophage-mediated phagocytosis and superoxide production (Sullivan 2003). Likewise, $\mathrm{A}_{2 \mathrm{~A}} \mathrm{AR}$ activation has profound effects on the adaptive immune response. $\mathrm{A}_{2 \mathrm{~A}} \mathrm{AR}$ activation inhibits both $\mathrm{CD} 4+$ and $\mathrm{CD} 8+\mathrm{T}$-cell function (Erdmann et al. 2005; Lappas et al. 2005; Naganuma et al. 2006; Sevigny et al. 2007; Zarek et al. 2008). Interestingly, $A_{2 A} A R$ activation on T cells seems to selectively inhibit proinflammatory cytokine expression while sparing anti-inflammatory cytokine expression (Naganuma et al. 2006). In addition, antigen activation in the presence of $A_{2 A} A R$ agonists can promote $\mathrm{T}$-cell tolerance in the form of anergy (Zarek et al. 2008). Likewise, $\mathrm{A}_{2 \mathrm{~A}} \mathrm{AR}$ engagement can prevent the development of IL-17 producing cells and promote the development of Foxp3+ and LAG-3+ regulatory T-cells. Along these lines, it has been shown that adenosine acting via the $\mathrm{A}_{2 \mathrm{~A}} \mathrm{AR}$ might partially mediate the suppressive function of regulatory $T$ cells by engaging the $\mathrm{A}_{2 \mathrm{~A}} \mathrm{ARs}$ on the suppressed cells (Deaglio et al. 2007). It was found that the ectoenzymes CD39 and CD73 appear to be more specific markers for Foxp $^{+}$regulatory cells than CD25 (Deaglio et al. 2007). Further data supporting the role of adenosine acting via the $\mathrm{A}_{2 \mathrm{~A}} \mathrm{AR}$ in facilitating regulatory $\mathrm{T}$-cell function has also been demonstrated in a colitis model of autoimmunity. In these studies, CD45RB ${ }^{\text {low }}$ or CD25 + T cells derived from $\mathrm{A}_{2 \mathrm{~A}} \mathrm{AR}$-null mice were unable to regulate $\mathrm{CD} 45 \mathrm{RB}^{\text {high }}$ cells and prevent disease (Naganuma et al. 2006). Furthermore, the CD45RB high cells from $A_{2 A} A R$-null mice were not inhibited by regulatory $\mathrm{T}$ cells, even when they were derived from wild-type mice (Naganuma et al. 2006). Thus, with regard to the adaptive immune response, the $A_{2 A} A R$ 
protects the host from excessive tissue destruction by not only acutely inhibiting T-cell function but also promoting the development of regulatory $\mathrm{T}$ cells.

\subsection{Adenosine Protects Tumors from Immune Destruction}

Tumors are very adept at usurping negative regulatory mechanisms of the immune system in order to evade antitumor responses. As mentioned above, the tumor microenvironment is replete with inhibitory cytokines, inhibitory ligands and regulatory $\mathrm{T}$ cells (Drake et al. 2006). Considering that $A_{2 A} A R$ activation is a potent inhibitor of adaptive immune responses, it is not surprising that tumor-derived adenosine has been implicated in blocking antitumor immunity. Indeed, the tumor microenvironment has been shown to contain relatively high concentrations of adenosine (Blay et al. 1997). In part, this is due to the hypoxic nature of the tumor microenvironment (Lukashev et al. 2007). Hypoxia regulates the levels of adenosine by inhibiting enzymes involved in the destruction of adenosine and simultaneously increasing the activity of enzymes charged with the generation of adenosine.

Hoskin and colleagues were one of the first groups to propose that adenosine within the microenvironment of solid tumors might inhibit T-cell function (Hoskin et al. 1994). Their initial studies demonstrated that adenosine could inhibit natural killer (NK) cell function as well as the ability of cytotoxic T cells to adhere to tumor cell targets (MacKenzie et al. 1994; Williams et al. 1997). Subsequently, this group went on to formally demonstrate that the extracellular fluid of tumors contains concentrations of adenosine that are sufficient to inhibit lymphocyte activation (Blay et al. 1997). This observation has since been confirmed by others (Ohta et al. 2006). Note that the initial studies by the Hoskin's group did not implicate the $\mathrm{A}_{2 \mathrm{~A}} \mathrm{AR}$ as playing a critical role in the inhibition of antitumor immune function. However, more recently it has been shown that adenosine can inhibit NK cell and IL-2/NKp46-activated NK cells specifically via the $A_{2 A} A R$ (Raskovalova et al. 2006). These studies showed that $\mathrm{A}_{2 \mathrm{~A}} \mathrm{AR}$-specific agonists inhibit the cytotoxicity of NK cells as well as their ability to elaborate cytokines. Interestingly, by employing various protein kinase $\mathrm{A}$ (PKA) inhibitors it was suggested that the ability of $\mathrm{A}_{2 \mathrm{~A}} \mathrm{AR}$ activation to inhibit these functions is mediated downstream via PKA-I but not PKA-II. It has subsequently been shown that $\mathrm{A}_{2 \mathrm{~A}} \mathrm{AR}$-specific agonists could also inhibit both tumor-specific CD4+ and CD8+ $T$ cells (Raskovalova et al. 2007). In these studies, similar to the NK cell studies, $A_{2 A} A R-$ specific agonists inhibited the ability of human antimelanoma-specific cytotoxic $\mathrm{T}$ lymphocytes (CTLs) and human anti-melanoma-specific CD4+ T cells with regard to their ability to kill tumor cells and elaborate cytokines and chemokines in response to tumor cells. Biochemically, it was found that molecules that activated PKA-I but not PKA-II mimicked the affects of $A_{2 A} A R$ activation on T-cell function. The $A_{2 A} A R$-mediated inhibition, in turn, was blocked by Rp-8-Br-cAMPS, which antagonizes the binding of cAMP to the regulatory subunit of PKA-I. Alternatively, inhibitors of the PKA catalytic subunit did not mitigate the inhibitory affects of $\mathrm{A}_{2 \mathrm{~A}} \mathrm{AR}$ activation.

As discussed, tumors evade host responses by acutely inhibiting immune function and promoting tolerance. Considering that $\mathrm{A}_{2 \mathrm{~A}} \mathrm{AR}$ activation inhibits immune responses by suppressing immune activation and promoting tolerance, the following question arises: does tumor-derived adenosine play this role in vivo? Initial studies addressing this question suggest that the answer is yes (Ohta et al. 2006). $\mathrm{A}_{2 \mathrm{~A}} \mathrm{AR}$-null mice have been shown to more readily reject melanoma and lymphoma tumor challenge. In addition, treating mice with $\mathrm{A}_{2 \mathrm{~A}} \mathrm{AR}$ antagonists (including caffeine) led to increased tumor rejection by $\mathrm{CD} 8+\mathrm{T}$ cells. These findings have been confirmed by another group that has also been able to demonstrate the ability of $\mathrm{A}_{2 \mathrm{~A}} \mathrm{AR}$-null mice to more readily reject tumors and respond more robustly to tumor vaccines (Powell et al., unpublished data). In particular, the data from these studies suggest that genetic deletion of the $\mathrm{A}_{2 \mathrm{~A}} \mathrm{AR}$ leads to more robust initial responses to vaccines. There are a number of important implications of these in vivo 
findings. First, the fact that genetic deletion of the $\mathrm{A}_{2 \mathrm{~A}} \mathrm{AR}$ markedly enhances antitumor responses suggests that adenosine plays an important role in mediating tumor evasion of the immune system. Second, adenosine appears to block both the generation and effector phases of antitumor responses. Third, and perhaps most importantly, these findings support a role for pharmacologic inhibition of $\mathrm{A}_{2 \mathrm{~A}} \mathrm{AR}$ activation as a means of enhancing immunotherapy.

\section{5 $\mathrm{A}_{2 \mathrm{~A}} \mathrm{AR}$ Antagonism as a Means of Enhancing Immunotherapy}

Adenosine acting via the $\mathrm{A}_{2 \mathrm{~A}} \mathrm{AR}$ has been shown to inhibit dendritic cell function, T-cell activation and differentiation, and T-cell effector function (Sitkovsky et al. 2004).

Additionally, the $\mathrm{A}_{2 \mathrm{~A}} \mathrm{AR}$ has been implicated in selectively enhancing anti-inflammatory cytokines, promoting the upregulation of PD- 1 and CTLA-4, promoting the generation of LAG-3 and Foxp3+ regulatory T cells, and mediating the inhibition of regulatory T cells (Naganuma et al. 2006; Sevigny et al. 2007; Zarek et al. 2008). All of these immunosuppressive properties have also been identified as mechanisms by which tumors evade host responses. Initial in vivo studies demonstrating that genetically and pharmacologically inhibiting the $\mathrm{A}_{2 \mathrm{~A}} \mathrm{AR}$ leads to robust antitumor responses suggest that adenosine is at least partially responsible for promoting these tumor defense mechanisms (Ohta et al. 2006). As such, the addition of $A_{2 A} A R$ antagonists to cancer immunotherapeutic protocols represents an exciting approach to enhancing tumor immunotherapy. Interestingly, the safety of such compounds has already been shown in trials employing $\mathrm{A}_{2 \mathrm{~A}} \mathrm{AR}$ antagonists for the treatment of Parkinson's disease (Jenner 2005).

Chemotherapy and radiation therapy result in the release of copious amounts of tumor antigen. However, this form of tissue destruction can also result in increases in extracellular adenosine. Therefore, the concomitant administration of $\mathrm{A}_{2 \mathrm{~A}} \mathrm{AR}$ antagonists during chemotherapy or radiation therapy might actually lead to the expansion of tumor-specific $\mathrm{T}$ cells, while at the same time preventing the induction of tumor-specific regulatory $\mathrm{T}$ cells. In terms of combining $\mathrm{A}_{2 \mathrm{~A}} \mathrm{AR}$ antagonists with tumor vaccines, we believe that there are two time points that are relevant. First, administration of antagonists during the perivaccination period might serve to enhance the generation of tumor-specific effector memory cells. This would be accomplished by both enhancing the activity of the antigen-presenting cells (e.g., dendritic cells), as well as blocking adenosine-mediated negative feedback on the $\mathrm{T}$ cells themselves. Second, the continued administration of $\mathrm{A}_{2 \mathrm{~A}} \mathrm{AR}$ antagonists will enhance the effector function of these cells and potentially block the upregulation of regulatory $\mathrm{T}$ cells. Finally, perhaps the most effective use of $\mathrm{A}_{2 \mathrm{~A}} \mathrm{AR}$ antagonists will be in combination with not only vaccines but also other checkpoint blockers. For example, blocking PD-1 engagement as well as the $\mathrm{A}_{2 \mathrm{~A}} \mathrm{AR}$ will perhaps mitigate the ability of tumors to turn off tumor-specific effector $\mathrm{T}$ cells.

\section{$4 \mathrm{~A}_{2 \mathrm{~B}}$ Adenosine Receptors}

The $A_{2 B}$ adenosine receptor $\left(A_{2 B} A R\right)$ is found in many different cell types and requires higher concentrations of adenosine for activation than the $A_{1}, A_{2 A}$, and $A_{3} A R$ subtypes (Fredholm et al. 2001). Thus, unlike the other AR subtypes, the $A_{2 B} A R$ is not stimulated by physiological levels of adenosine, but may therefore play an important role in pathophysiological conditions associated with massive adenosine release. Such conditions occur in ischemia or in tumors where hypoxia is commonly observed (Illes et al. 2000; Merighi et al. 2003). Although potent and selective tools are scarce for the $A_{2 B} A R$ subtype, it has become increasingly clear in recent years that this AR subtype regulates a number of functions (e.g., vascular tone, cytokine release, and angiogenesis; Volpini et al. 2003). $\mathrm{A}_{2 \mathrm{~B}}$ ARs may also play a role in cancer, based on a number of observations. Gaining an understanding of the exact mechanisms by which adenosine regulates the growth and proliferation of tumor cells via this AR subtype could potentially lead to a target for novel 
therapies or at least for cotherapies for cancer. In the following sections, potential mechanisms suggesting that $\mathrm{A}_{2 \mathrm{~B}} \mathrm{AR}$ might be involved in tumor development and progression are discussed.

One of the pivotal mechanisms for tumor growth is angiogenesis, a process that is highly regulated by an array of angiogenic factors and is triggered by adenosine under various circumstances that are associated with hypoxia. Although the $\mathrm{A}_{3} \mathrm{AR}$ subtype is involved in the release of angiogenic factors, in some cases the $\mathrm{A}_{2 \mathrm{~B}} \mathrm{AR}$ also seems to be responsible for the release of a certain subset of cytokines (Feoktistov et al. 2003; Merighi et al. 2007). $\mathrm{A}_{2 \mathrm{~B}} \mathrm{ARs}$ are expressed in human microvascular endothelial cells, where they play a role in the regulation of the expression of angiogenic factors like vascular endothelial growth factor (VEGF), IL-8, and basic fibroblast growth factor (bFGF) (Feoktistov et al. 2002). Moreover, in HMC-1 cells derived from a highly malignant, undifferentiated human mastocytoma cancer, activation of $\mathrm{A}_{2 \mathrm{~B}} \mathrm{ARs}$ induces the release of IL-8 and VEGF, and the activation of $\mathrm{A}_{3}$ ARs induces angiopoietin 2 expression (Feoktistov et al. 2003). However, capillary formation induced by HMC-1 media was maximal when both HMC-1 $\mathrm{A}_{2 \mathrm{~B}} \mathrm{ARs}$ and $\mathrm{A}_{3} \mathrm{ARs}$ were activated. Activation of $\mathrm{A}_{2 \mathrm{~B}} \mathrm{ARs}$ alone was less effective, suggesting a cooperation between $\mathrm{A}_{2 \mathrm{~B}} \mathrm{ARs}$ and $\mathrm{A}_{3} \mathrm{ARs}$ on $\mathrm{HMC}-1$ cells to produce angiogenesis. Furthermore, Merighi et al. demonstrated in HT29 human colon cancer cells that adenosine increases IL-8 expression via stimulation of $\mathrm{A}_{2 \mathrm{~B}} \mathrm{ARs}$, while the stimulation of $\mathrm{A}_{3} \mathrm{AR}$ caused an increase in VEGF (Merighi et al. 2007). In the glioblastoma cell line U87MG, a similar $A_{2 B} A R-$ mediated increase of IL-8 was observed (Zeng et al. 2003). In addition, it was shown that hypoxia caused an upregulation of $\mathrm{A}_{2 \mathrm{~B}} \mathrm{ARs}$ in these tumor cells. As these findings point to a crucial role for $\mathrm{A}_{2 \mathrm{~B}} \mathrm{ARs}$ in mediating the effects of adenosine on angiogenesis, blockade of $\mathrm{A}_{2 \mathrm{~B}} \mathrm{ARs}$ may limit tumor growth by limiting the oxygen supply.

There are numerous reports of a potential role of adenosine and ARs in breast cancer (Barry and Lind 2000; Madi et al. 2004; Panjehpour et al. 2005; Spychala et al. 2004). Although $\mathrm{AR}$ agonists acting through $\mathrm{A}_{3} \mathrm{ARs}$ were shown to possess antitumor activity in breast cancer, it turned out (at least in some cases) that these effects were receptor independent (Chung et al. 2006; Lu et al. 2003). The very high concentrations of IB-MECA required for growth inhibition in some studies (Panjehpour and Karami-Tehrani 2004) may lend further support to the notion of $\mathrm{A}_{3} \mathrm{AR}$-independent effects.

A most striking observation was that the estrogen receptor-positive MCF-7 cells appeared to be devoid of any detectable amount of ARs, whereas the estrogen receptor-negative MDAMB-231 cells express very high levels of $A_{2 B} A R s$ (Panjehpour et al. 2005). Both binding and functional experiments showed that other AR subtypes were not present in detectable levels in these tumor cells. Stimulation with the nonselective AR agonist $5^{\prime}-(\mathrm{N}-$ ethylcarboxamido)adenosine (NECA) resulted in the activation of adenylate cyclase, whereas $10 \mu \mathrm{M}$ 2-p-(2-carboxyethyl)phenethylamino-5' $-N$-ethylcarboxamidoadenosine (CGS21680; which, at this concentration, activates all but the $\mathrm{A}_{2 \mathrm{~B}} \mathrm{AR}$ subtype) had no effect. Moreover, there was no $\mathrm{A}_{1} \mathrm{AR}$ or $\mathrm{A}_{3} \mathrm{AR}$ receptor-mediated inhibition of adenylate cyclase, confirming the exclusive presence of $A_{2 B} A R s$ as a functionally relevant $A R$ subtype in MDA-MB-231 cells (Panjehpour et al. 2005).

In addition to the classical adenylate cyclase activation, $\mathrm{A}_{2 \mathrm{~B}} \mathrm{ARs}$ also mediate a $\mathrm{Ca}^{2+}$ signal (Feoktistov et al. 1994; Linden et al. 1999; Mirabet et al. 1997). A similar $\mathrm{Ca}^{2+}$ signal was detected in MDA-MB-231 cells, most likely as a result of the activation of $\mathrm{G}_{\mathrm{q}}$ (Panjehpour et al. 2005). With the use of selective agonists and antagonists for $A_{1} A R, A_{2} A R$, and $\mathrm{A}_{3} \mathrm{ARs}$, a pharmacological profile identical to the one found for the adenylate cyclase response was demonstrated for the $\mathrm{Ca}^{2+}$ signal in these cells, again suggesting an $\mathrm{A}_{2 \mathrm{~B}} \mathrm{AR}$ as the sole AR subtype in these cells. 
The mitogen-activated protein (MAP) kinase pathways are critically important in the regulation of cell proliferation and differentiation (Raman et al. 2007). There are numerous extracellular signals feeding into these cascades, including input via GPCRs (Goldsmith and Dhanasekaran 2007). All four subtypes of ARs were shown to mediate extracellular signalregulated kinase (ERK) 1/2 phosphorylation in transfected CHO cells (Graham et al. 2001; Schulte and Fredholm 2000). MAP kinase signaling and hence cell proliferation might be amenable to manipulation through specific ARs in tumor cells. Such a possibility seems to be particularly attractive in a situation where one AR subtype is highly expressed, as is the case for $A_{2 B} A R s$ in MDA-MB-231 cells. As mentioned above, $A_{2 B}$ ARs are stimulated only by patho-physiologically high concentrations of adenosine (Fredholm et al. 2001). Thus, selective blockade or stimulation of this AR subtype may not interfere with the numerous important physiological functions of adenosine mediated via other AR subtypes.

MDA-MB-231 cells show a very high basal ERK 1/2 phosphorylation, indicative of constitutively active growth signals (Bieber et al. 2008). This basal activity seems to be maximal, as stimulation of the MAP kinase pathway (e.g., with epidermal growth factor, EGF) does not cause a further increase in ERK phosphorylation. The nonselective AR agonist NECA, on the other hand, causes a time-dependent decrease in ERK 1/2 phosphorylation, whereas CGS 21680 shows no inhibitory effect. As described above, functional and binding studies suggest that only $\mathrm{A}_{2 \mathrm{~B}} \mathrm{ARs}$ are present in MDA-MB-231 cells. Therefore, it seems that this AR subtype is responsible for the unusual inhibitory signal on ERK 1/2 phosphorylation. Moreover, antagonists like 1,3-dipropyl-8-cyclopentylxanthine (DPCPX) block this response, confirming the identity of the AR subtype as the $\mathrm{A}_{2 \mathrm{~B}} \mathrm{AR}$ mediating the inhibition of ERK 1/2 phosphorylation (Bieber et al. 2008).

The exact pathway leading to $\mathrm{A}_{2 \mathrm{~B}} \mathrm{AR}$-mediated inhibition is not fully understood at this point. Both the $\mathrm{Ca}^{2+}$ signal detected following $\mathrm{A}_{2 \mathrm{~B}} \mathrm{AR}$ stimulation in MDA-MB-231 cells (Panjehpour et al. 2005) and PLC activation are sufficient, as their blockade abolishes the inhibition of ERK 1/2 phosphorylation. On the other hand, forskolin stimulation mimics the effect of NECA, suggesting that cAMP may also play a role. Several inhibitors of PKA have no effect on NECA-induced inhibition of ERK 1/2 phosphorylation. Similarly without effect are activators of PKA and exchange protein activated by cAMP (Epac), making these effectors unlikely to be targets involved in mediating the inhibitory $A_{2 B} A R$ signal on MAP kinase activity. Figure 1 summarizes the current knowledge of potential pathways leading to $\mathrm{A}_{2 \mathrm{~B}} \mathrm{AR}-\mathrm{mediated}$ inhibition of ERK 1/2 phosphorylation in MDA-MB-231 cells.

Although it was shown that $\mathrm{A}_{2 \mathrm{~B}} \mathrm{ARs}$ convey a stimulatory signal into MAP kinase pathways in transfected CHO cells (Schulte and Fredholm 2000), an inhibitory input was found in MDA-MB-231 cells. A few studies describe such an uncommon antiproliferative GPCRmediated signal in glomerular mesangial cells (Haneda et al. 1996) and in vascular smooth muscle cells (Dubey et al. 2000). The high expression levels of $A_{2 B} A R s$ in an estrogennegative breast cancer cell line together with a link to an antiproliferative signaling pathway make this AR subtype a potentially interesting target for tumor treatment, perhaps in combination with drugs interfering with downstream effectors in MAP kinase signaling pathways (Dhillon et al. 2007).

There is an increasing amount of data confirming that $\mathrm{A}_{2 \mathrm{~B}} \mathrm{ARs}$ play an important role in mediating the effects of adenosine on tumor growth and progression. The effects which are most interesting for a potential anticancer treatment based on $\mathrm{A}_{2 \mathrm{~B}} \mathrm{ARs}$ as a target are inhibition of angiogenesis and inhibition of ERK $1 / 2$ phosphorylation. The dilemma is, however, that inhibition of angiogenesis requires the use of $\mathrm{A}_{2 \mathrm{~B}} \mathrm{AR}$ antagonists, whereas inhibition of growth signaling via the MAP kinase pathway might be achieved through treatment with $\mathrm{A}_{2 \mathrm{~B}} \mathrm{AR}$ agonists. The relative importance of these effects needs to be 
investigated using in vivo models before therapeutic suggestions can arise. It may eventually turn out that both agonists and antagonists will provide useful options for treatment in combination with other therapeutic measures if used at different stages of the disease and its treatment.

\section{$5 \mathrm{~A}_{3}$ Adenosine Receptor}

$\mathrm{A}_{3} \mathrm{AR}$ belongs to the family of seven-transmembrane-domain GPCRs. The human $\mathrm{A}_{3} \mathrm{AR}$ has been cloned and expressed and its adenosine agonist binding specificities characterized. The $A_{3} A R$ was found to be most abundantly expressed in human lung and liver, with low amounts observed in the brain (Sajjadi and Firestein 1993). Low levels of expression were also observed in testes and heart. No expression was found in spleen or kidney. This expression profile differed from those for the $A_{1} A R, A_{2 A} A R$ and $A_{2 B} A R$, which are expressed in variable levels in brain, heart, lung and kidney but not in liver tissues (Salvatore et al. 1993). Ligand structure-activity studies have identified selective agonists, partial agonists and antagonists for ARs (Cristalli et al. 2003; Muller 2003; Volpini et al. 2003; Zablocki et al. 2004). For the human and rat $\mathrm{A}_{3} \mathrm{AR}$, potent and selective agonists as well as selective $\mathrm{A}_{3}$ AR antagonists (e.g., PSB-10, PSB-11, MRE-3005F20 and MRS-1334) have been identified (Muller 2003). Site-directed mutagenesis and molecular modeling studies have also been performed that provide detailed information about the physical properties of ligand binding sites and the process of receptor activation (Gao et al. 2002; Muller 2003). Because of their selective tissue distribution and the development of specific $\mathrm{A}_{3} \mathrm{AR}$ agonists and antagonists for them, $\mathrm{A}_{3} \mathrm{ARs}$ have recently attracted considerable interest as novel drug targets.

Agonists to the $\mathrm{A}_{3} \mathrm{AR}$ exert a differential effect on normal and tumor cells. In normal cells, the agonists induce the production of growth factors via induction of the NF- $\kappa$ B signaling pathway. In contrast, in tumor cells, the agonists induce apoptosis and tumor growth inhibition via deregulation of the NF- $\mathrm{kB}$ and the Wnt signaling pathways. This will be further detailed in Sect. 5.4.1 of this chapter.

Moreover, $\mathrm{A}_{3} \mathrm{AR}$ agonists showed efficacy as cardioprotective, cerebroprotective, antiinflammatory and immunosuppressive agents (Bar-Yehuda et al. 2007; Chen et al. 2006; Xu et al. 2006). For additional information on the pharmacology of the $A_{3} A R$ and its role in disease, the reader is referred to Chap. 10, " $\mathrm{A}_{3}$ Adenosine Receptor: Pharmacology and Role in Disease" (by Borea et al.), in this volume.

In this manuscript, the activity of $\mathrm{A}_{3} \mathrm{AR}$ ligands as anticancer and chemoprotective agents will be presented. In addition, various aspects of $\mathrm{A}_{3} \mathrm{AR}$-targeted therapy, mainly in solid tumor malignancies such as melanoma, prostate, colon and hepatocellular carcinoma (HCC), will be discussed. Signal transduction pathways involved with $\mathrm{A}_{3} \mathrm{AR}$ targeting utilizing highly selective $\mathrm{A}_{3} \mathrm{AR}$ agonists and antagonists will be presented.

A significant part of the review is dedicated to the therapeutic effect of $A_{3} A R$ agonists based on the concept that these compounds target mainly malignant cells that highly express $\mathrm{A}_{3} \mathrm{ARs}$ without damaging normal body cells that barely express the receptor.

\subsection{Overexpression of the $A_{3} A R$ in Tumor Versus Normal Adjacent Tissues}

Earlier studies revealed $\mathrm{A}_{3} \mathrm{AR}$ expression in tumor cell lines including astrocytoma, HL-60 leukemia, B16-F10 and A378 melanoma, human Jurkat T-cell lymphoma, and murine pineal tumor cells, whereas low expression was described in most normal tissues (Auchampach et al. 1997; Gessi et al. 2002; Madi et al. 2003; Merighi et al. 2001; Suh et al. 2001; Trincavelli et al. 2002). 
In more recent studies, a comparison between $\mathrm{A}_{3} \mathrm{AR}$ expression in tumor vs. adjacent and relevant normal tissues supported the assumption that the receptor is upregulated in different types of malignancies. Recently, $\mathrm{A}_{3} \mathrm{AR}$ in solid tumors was analyzed, leading to robust findings showing overexpression of the $\mathrm{A}_{3} \mathrm{AR}$ in tumor tissues vs. low expression in the adjacent normal tissues. Furthermore, there is substantial evidence showing that $\mathrm{A}_{3} \mathrm{AR}$ expression level is directly correlated to disease severity (Gessi et al. 2004; Madi et al. 2004).

In a comparative study, Morello et al. showed that primary thyroid cancer tissues express high levels of $\mathrm{A}_{3} \mathrm{ARs}$, as determined by immunohistochemistry analysis, whereas normal thyroid tissue samples do not express $\mathrm{A}_{3} \mathrm{ARs}$ (Morello et al. 2007). Gessi et al. looked at the receptor binding values $\left(K_{\mathrm{d}}\right.$ and $\left.B_{\max }\right)$ of the $\mathrm{A}_{3} \mathrm{AR}$ ligand $\left[{ }^{3} \mathrm{H}\right.$ ]MRE $3008 \mathrm{~F} 20$ in colon carcinoma tissue samples from 73 patients, and found an increased binding value in comparison to adjacent, remote and healthy colon mucosa (Gessi et al. 2004). Interestingly, they found that large adenomas showed increased binding versus small adenomas, which had affinity and density values that were very similar to those of the mucosa of healthy subjects. An additional important result of this study was that the high receptor binding values ( $K_{\mathrm{d}}$ and $\left.B_{\mathrm{max}}\right)$ were reflected in the peripheral blood lymphocytes and neutrophils of the patients with colon carcinoma. Upon tumor resection, the $\mathrm{A}_{3} \mathrm{AR}$ binding value $\left(K_{\mathrm{d}}\right.$ and $\left.B_{\max }\right)$ returned to that of the healthy subjects, suggesting that the receptor may also serve as a biological marker (Gessi et al. 2004). Similar data were reported by Madi et al. showing higher $\mathrm{A}_{3} \mathrm{AR}$ protein and mRNA expression levels in colon and breast carcinomas vs. adjacent non-neoplastic tissue or normal tissue (Madi et al. 2004). Further analysis revealed that the lymph node metastasis expressed even more $\mathrm{A}_{3} \mathrm{AR}$ mRNA levels than the primary tumors, supporting the notion that $\mathrm{A}_{3} \mathrm{AR}$ levels may reflect the status of tumor progression (Madi et al. 2004).

Madi et al. also reported that in human melanoma, colon, breast, small-cell lung, and pancreatic carcinoma tissues, $\mathrm{A}_{3} \mathrm{AR}$ mRNA was upregulated compared to adjacent nonneoplastic tissue and normal tissue derived from healthy subjects (Madi et al. 2004). Moreover, computational analysis using different database sources supported the biological analysis that $A_{3} A R$ is overexpressed in tumor tissues (Madi et al. 2004). A 2.3-fold increase in the expression of $\mathrm{A}_{3} \mathrm{AR}$ in human colon adenoma versus normal colon tissue using microarray analysis (Princeton University database) was found. A search in the Cancer Genome Anatomy Project (CGAP); SAGE (website: http://cgap.nci.nih.gov/SAGE; Virtual Northern Legend) based on serial analysis of gene expression revealed that $\mathrm{A}_{3} \mathrm{AR}$ was abundant in brain, kidney, lung, germ cells, placenta and retina, but that brain, lung, and pancreatic tumors expressed more $\mathrm{A}_{3} \mathrm{AR}$ in the malignant than the normal non-cancerous tissues from the same organs of the same patients. A search of the Expression Viewer (Human Genome Organization (HUGO) Gene Nomenclature Committee/CleanEX) based on expressed sequence tags revealed that the relative expression of $\mathrm{A}_{3} \mathrm{AR}$ was 1.6-fold higher in all of the cancer tissues compared with normal tissues (Madi et al. 2004).

In a recent study, Bar-Yehuda et al. showed that $\mathrm{A}_{3} \mathrm{AR}$ mRNA expression is upregulated in HCC tissues in comparison to adjacent normal tissues (Bar-Yehuda et al. 2008).

Remarkably, upregulation of $\mathrm{A}_{3} \mathrm{AR}$ was also noted in peripheral blood mononuclear cells (PBMCs) derived from the HCC patients compared to healthy subjects. These results further show that $\mathrm{A}_{3} \mathrm{AR}$ in PBMCs reflect receptor status in the remote tumor tissue (Bar-Yehuda et al. 2008). Moreover, the high expression level of the $A_{3} A R$ was directly correlated to overexpression of NF- $\mathrm{kB}$, a transcription factor for the $\mathrm{A}_{3} \mathrm{AR}$.

It is well established that $\mathrm{G}_{\mathrm{i}}$-protein-coupled receptors are internalized to early endosomes upon agonist binding (Bunemann et al. 1999; Claing et al. 2002). Early endosomes serve as 
the major site of receptor recycling, whereas the late endosomes are involved with the delivery of the internalized receptor to the lysosomes (Bunemann et al. 1999; Claing et al. 2002). Former studies have shown that chronic exposure of the $A_{3} A R$ to the specific agonist methyl-1-[ $\Lambda^{6}$-(3-iodobenzyl)-adenin-9-yl]- $\beta$-D-ribofuronamid (IB-MECA) resulted in receptor internalization/externalization in B16-F10 melanoma cells (Madi et al. 2003). It was also demonstrated that in experimental animal xenograft models of colon and prostate carcinoma, chronic treatment with IB-MECA (designated CF101) induced receptor downregulation shortly after agonist administration. Interestingly, $24 \mathrm{~h}$ after treatment there was no tachyphylaxis and the $\mathrm{A}_{3} \mathrm{AR}$ was fully expressed, showing that the target is not downregulated upon chronic treatment with the agonist (Fishman et al. 2003, 2004).

The data showing a direct correlation in $\mathrm{A}_{3} \mathrm{AR}$ expression between tumor tissue and PBMCs suggest that receptor expression in the PBMCs mirrors receptor status in the tumor tissue. It is possible that TNF- $a$ upregulation induces an increase in the expression level and activity of NF- $\kappa$ B, a transcription factor for $\mathrm{A}_{3} \mathrm{ARs}$ (Madi et al. 2004). This assumption is supported by the following finding. Upon treatment with 2-chloro- $N^{6}-3$-iodobenzyladenosine- $5^{\prime}-N$ methyluronamide (Cl-IB-MECA; designated CF102), the expression levels of TNF- $a$ and $\mathrm{NF}-\mathrm{\kappa B}$ were decreased, resulting in a downregulation of $\mathrm{A}_{3} \mathrm{AR}$ expression in both PBMCs and the tumor tissue (Bar-Yehuda et al. 2008). Similar data were reported by Gessi et al., showing that $\mathrm{A}_{3} \mathrm{AR}$ is upregulated in both colon carcinoma tissue and PBMCs of patients with colon carcinoma. This group further demonstrated that the expression levels of $\mathrm{A}_{3} \mathrm{AR}$ were downregulated in the PBMCs upon tumor removal (Gessi et al. 2004).

Taken together, the findings described above that show $\mathrm{A}_{3} \mathrm{AR}$ overexpression in different tumor cell types provide the rationale that this receptor may be utilized as a specific target to treat cancer.

\subsection{In Vitro Studies}

The $\mathrm{A}_{3} \mathrm{AR}$ plays an important role in regulating normal and tumor cell growth. Cell response to a given $A_{3} A R$ agonist is determined by a plethora of factors, including agonist concentration and affinity, receptor density, interaction between different ARs expressed on the cell surface, cell type, and the cell microenvironment.

5.2.1 Effect of Low-Concentration $A_{3} A R$ Agonists on Tumor Cell Growth-The effects of $\mathrm{A}_{3} \mathrm{AR}$ agonists, mainly IB-MECA and Cl-IB-MECA, on the proliferation of various tumor cells have been extensively tested. The rationale for using low concentrations of these two $\mathrm{A}_{3} \mathrm{AR}$ agonists was based on their high affinity and selectivity at the $\mathrm{A}_{3} \mathrm{AR}$ (approximately three orders of magnitude more than at the other ARs) (Fishman et al. 2007; Jeong et al. 2004; Joshi and Jacobson 2005). Moreover, Phase I clinical studies in healthy subjects, testing of IB-MECA (designated CF101) showed that the maximal tolerated dose of the drug was $5 \mathrm{mg} \mathrm{kg}^{-1}$. At this dose, the plasma concentration was $40 \mathrm{ng} \mathrm{ml}^{-1}$, which correlates with a concentration of $20 \mathrm{nM}$ (van Troostenburg et al. 2004). This value correlates nicely with the affinity of IB-MECA to the mouse/rat/human $\mathrm{A}_{3} \mathrm{AR}$, exclusively activating this AR subtype, not any other AR subtype. Based on these data, IB-MECA and $\mathrm{Cl}-\mathrm{IB}-\mathrm{MECA}$ were tested both in vitro and in vivo at low concentrations and dosages, respectively. Remarkably, at this low concentration range these agonists induced a differential effect on tumor and normal cell proliferation.

Inhibition of the growth of tumor cells, including rat $\mathrm{Nb} 2-11 \mathrm{C}$ and mouse Yac-1 lymphoma, K-562 leukemia, B16-F10 melanoma, MCA sarcoma, human LN-Cap and PC3 prostate carcinoma, MIA-PaCa pancreatic carcinoma and HCT-116 colon carcinoma, was found. The agonists induced a cytostatic effect towards the tumor cells, as manifested by a decrease in ${ }^{3}[\mathrm{H}]$ thymidine incorporation and cell cycle arrest at the $\mathrm{G}_{0} / \mathrm{G}_{1}$ phase (Bar-Yehuda et al. 
2001; Fishman et al. 2000a, 2001, 2002a, b, 2003; Merimsky et al. 2003; Ohana et al. 2003). This effect was abolished by $\mathrm{A}_{3} \mathrm{AR}$ antagonists (Madi et al. 2003), demonstrating that the response was $\mathrm{A}_{3} \mathrm{AR}$ mediated. IB-MECA enhanced the cytotoxic effect of chemotherapy when tested in 1-(4,5-dimethylthiazol-2-yl)-3,5-diphenylformazan thiazolyl (MTT) and colony formation assays. A combined treatment of 5-flurouracil plus IB-MECA yielded higher growth inhibition of HCT-116 human colon carcinoma cells in comparison to the chemotherapy alone (Bar-Yehuda et al. 2005).

At the same time, Cl-IB-MECA stimulated the proliferation of bone marrow cells (Fishman et al. 2001). Interestingly, both IB-MECA and Cl-IB-MECA up-regulated the production of granulocyte colony stimulating factor (G-CSF), known to act as a differentiation factor of neutrophils (Brandt et al. 1988). This novel activity mediated the stimulatory effect on bone marrow cell growth and prompted the examination of IB-MECA and Cl-IB-MECA as myeloprotective agents that prevent neutropenia upon treatment with chemotherapeutic agents (Bar-Yehuda et al. 2002, Fishman et al. 2000b, 2001, 2002b, 2003).

As opposed to the results of the studies described above, demonstrating an inhibition of tumor cell lines by $\mathrm{A}_{3} \mathrm{AR}$ agonists, in a set of experiments conducted by Gessi et al., lowconcentration (100 nM) Cl-IB-MECA stimulated the proliferation of some cancer cell lines such as Caco-2, DLD1, and HT29 human colon carcinoma cell line (Gessi et al. 2007). In addition, the same group showed that under hypoxic conditions, Cl-IB-MECA induced upregulation of hypoxia-inducible factor 1 (HIF-1) alpha and VEGF in HT-29 human colon carcinoma cells, A375 human melanoma cells, and A172 and U87MG glioblastoma cell lines. This effect could be blocked with the $\mathrm{A}_{3} \mathrm{AR}$ antagonist (MRE3008F20) or by siRNA silencing (Merighi et al. 2005b, 2006, 2007). Moreover, Abbracchio et al. showed that $\mathrm{Cl}-$ IB-MECA modulates cytoskeleton reorganization, increases expression of Rho, and induces the intracellular distribution of the antiapoptotic protein $\mathrm{Bcl}-\mathrm{xL}$ in $\mathrm{ADF}$ human astrocytoma cells (Abbracchio et al. 1997, 2001). Thus, A $_{3}$ AR agonists can on the one hand induce the inhibition of tumor cell growth via cell cycle arrest, and on the other hand stimulate the proliferation of tumor cells, depending on cell type and culture conditions.

5.2.2 Effect of High-Concentration $A_{3} A R$ Agonists on Tumor Cell Growth-The effect of high-concentration $\mathrm{A}_{3} \mathrm{AR}$ agonists on tumor cell growth was an inhibitory one that was either $\mathrm{A}_{3} \mathrm{AR}$ dependent or independent. Cl-IB-MECA at a concentration of $10 \mu \mathrm{M}$ inhibited the growth of A375 human melanoma cells by inducing cell cycle arrest in the $\mathrm{G}_{0} /$ $\mathrm{G}_{1}$ phase. This effect was blocked by an $\mathrm{A}_{3} \mathrm{AR}$ antagonist, demonstrating the role of $\mathrm{A}_{3} \mathrm{AR}$ activation in this response (Merighi et al. 2005a). Moreover, IB-MECA at high concentration (30-60 $\mu \mathrm{M})$ produced cell growth inhibition in both ERa-positive MCF-7 cells and in ERa-negative MDAMB468 human breast carcinoma cells. In both cell types, the introduction of an $\mathrm{A}_{3} \mathrm{AR}$ antagonist, MRS1220, blocked the effect of this $\mathrm{A}_{3} \mathrm{AR}$ agonist (Panjehpour and Karami-Tehrani 2004, 2007).

The $\mathrm{A}_{3} \mathrm{AR}$ agonist 2-chloro- $N^{6}$-(3-iodobenzyl)- $4^{\prime}$-thioadenosine- $5^{\prime}-N$-methyluronamide (thio-Cl-IB-MECA) has high affinity and specificity for the human $\mathrm{A}_{3} \mathrm{AR}$. The introduction of $\mu \mathrm{M}$ concentrations of this agonist to HL-60 human leukemia cell cultures resulted in apoptosis, as manifested by DNA fragmentation and poly(ADP-ribose) polymerase (PARP) cleavage (Lee et al. 2005).

Interestingly, an additional compound that inhibits the growth of tumor cells via $\mathrm{A}_{3} \mathrm{AR}$ is cordycepin ( $3^{\prime}$-deoxyadenosine), an active ingredient of Cordyceps sinensis, a parasitic fungus used in traditional Chinese medicine (Nakamura et al. 2006). This molecule, at $\mu \mathrm{M}$ concentrations, induced a remarkable inhibitory effect on the growth of murine B16-BL6 melanoma and of Lewis lung carcinoma tumor cells. This inhibitory effect was abolished by 
the $\mathrm{A}_{3} \mathrm{AR}$ antagonist 3-ethyl-5-benzyl-2-methyl-4-phenylethynyl-6-phenyl-1,4-( \pm -) dihydropyridine-3,5-dicarboxylate MRS1191 (Nakamura et al. 2006).

In contrast, IB-MECA and Cl-IB-MECA at $\mu \mathrm{M}$ concentrations inhibit the growth of various tumor cell lines (including NPA papillary thyroid carcinoma, HL-60 leukemia cells and U-937 lymphoma cells) in an A AR-independent mechanism (Kim et al. 2002; Morello et al. 2007). This inhibitory effect was characterized by apoptosis and was not abolished by antagonism or knockdown of the $\mathrm{A}_{3} \mathrm{AR}$. Based on these results, it was concluded that IBMECA or Cl-IB-MECA at high concentrations can induce tumor cell death through receptor-independent mechanisms, perhaps via active transport into the cells through the nucleoside transporters (Kim et al. 2002; Merighi et al. 2002; Morello et al. 2007). Moreover, in MCF-7 human breast cancer cells, $100 \mu \mathrm{M}$ of IB-MECA markedly reduced cell number and inhibited colony formation ( $\mathrm{Lu}$ et al. 2003). These cancer cells do not express $\mathrm{A}_{3} \mathrm{ARs}$, overexpression of $\mathrm{A}_{3} \mathrm{AR}$ did not lower the concentrations of IB-MECA needed to induce the inhibition of cell proliferation, and the introduction of MRS1191 (an $\mathrm{A}_{3} \mathrm{AR}$ antagonist) did not abolish the IB-MECA inhibitory effect, suggesting that $\mathrm{A}_{3} \mathrm{AR}$ was not involved in the cell growth inhibition of these human breast cancer cells. In these studies, an explanation for this inhibitory effect by IB-MECA may be related to its ability to reduce the expression level of estrogen receptor (ER) alpha, which plays a role in different signaling pathways leading to the transcription of genes responsible for $\mathrm{G}_{1}-\mathrm{S}$ cell cycle progression (Lu et al. 2003). The effects of the various $A_{3} A R$ agonists at low and high concentrations on tumor cell growth in in vitro studies are summarized in Table 1.

\subsection{In Vivo Studies}

In this part of the review, in vivo studies showing the efficacy of $\mathrm{A}_{3} \mathrm{AR}$ agonists in various tumor-bearing animals will be presented, supporting the utilization of $\mathrm{A}_{3} \mathrm{AR}$ as a target to treat cancer. In all experimental models, the $\mathrm{A}_{3} \mathrm{AR}$ agonists were administered orally due to their stability and bioavailability profile. The dose used in these studies was calculated based on the affinity data, resulting in exclusive activation of the $\mathrm{A}_{3} \mathrm{AR}$. The studies included syngeneic, xenograft, orthotopic and metastatic experimental animal models utilizing IBMECA and Cl-IB-MECA as the therapeutic agents.

5.3.1 Melanoma-Oral administration of 10-100 $\mu \mathrm{g} \mathrm{kg}^{-1}$ IB-MECA and Cl-IB-MECA once or twice daily inhibited the growth of primary B16-F10 murine melanoma tumors in syngeneic models (Madi et al. 2003). Moreover, in an artificial metastatic model, IB-MECA inhibited the development of B16-F10 murine melanoma lung metastases (Bar-Yehuda et al. 2001; Fishman et al. 2001, 2002b). The specificity of the response was demonstrated by the administration of an $\mathrm{A}_{3} \mathrm{AR}$ antagonist that reversed the effect of the agonist (Madi et al. 2003).

Furthermore, IB-MECA or Cl-IB-MECA in combination with the chemotherapeutic agent cyclophosphamide induced an additive antitumor effect on the development of B16-F10 melanoma lung metastatic foci (Fishman et al. 2001, 2002b).

5.3.2 Colon Carcinoma-Oral administration of $10-100 \mu \mathrm{g} \mathrm{kg}^{-1}$ IB-MECA once or twice daily inhibited the growth of primary CT-26 colon tumors (Ohana et al. 2003). Furthermore, in xenograft models, IB-MECA inhibited the development of HCT-116 human colon carcinoma in nude mice (Ohana et al. 2003). In these studies, the combined treatment of IB-MECA and 5-fluorouracil resulted in an enhanced antitumor effect. IBMECA was also efficacious in inhibiting liver metastases of CT-26 colon carcinoma cells inoculated in the spleen. (Bar-Yehuda et al. 2005; Fishman et al. 2002b, 2004; Ohana et al. 2003). 
5.3.3 Prostate Carcinoma-IB-MECA inhibited the development of PC3 human prostate carcinoma in nude mice. Additionally, IB-MECA increased the cytotoxic index of Taxol in PC3 prostate carcinoma-bearing mice (Fishman et al. 2002b, 2003).

5.3.4 Hepatocellular Carcinoma-Recent studies showed that $A_{3} A R$ is overexpressed in tumor tissues and in PBMCs of N1S1 HCC tumor-bearing Sprague-Dawley rats (BarYehuda et al. 2008). For these studies, an orthotopic rat model was established in which a subxiphoid laparotomy was performed and N1S1 cells were injected into the right hepatic lobe. Treatments with Cl-IB-MECA at doses of 1, 50, 100, 500 and $1,000 \mu \mathrm{g} \mathrm{kg}^{-1}$ three times daily were initiated on day 3 after tumor inoculation and continued until day 15 . ClIB-MECA treatment exerted a bell-shaped, dose-dependent inhibitory effect on tumor growth with a maximal effect at a dose of $100 \mu \mathrm{g} \mathrm{kg}^{-1}$ (Bar-Yehuda et al. 2008).

5.3.5 Potentiation of Natural Killer Cell Activity-IB-MECA and Cl-IB-MECA also upregulate serum levels of IL-12 and potentiate NK cell activity (Harish et al. 2003). In mice, Cl-IB-MECA increased serum levels of IL-12 and potentiated the activity of NK cells (Harish et al. 2003). This effect of Cl-IB-MECA on NK cell activity was seen in adoptive transfer experiments utilizing melanoma-bearing mice where marked inhibition in the development of lung metastatic foci was observed in the mice engrafted with splenocytes derived from Cl-IB-MECA treated mice. Similar results were observed in HCT-116 human colon carcinoma-bearing nude mice treated with $10 \mu \mathrm{g} \mathrm{kg}^{-1}$ IB-MECA (Ohana et al. 2003).

\subsubsection{Chemoprotective Effect-IB-MECA and Cl-IB-MECA act also as} chemoprotective agents. With cyclophosphamide treatment of B16-F10 melanoma-bearing mice or 5-fluorouracil treatment of HCT-116 human colon carcinoma-bearing nude mice, a marked decline in white blood cells and neutrophil counts occurs (Bar-Yehuda et al. 2002; Fishman et al. 2000b, 2001, 2002a, b, 2003). Administration of the $A_{3} A R$ agonist restored the number of white blood cells and the percentage of neutrophils to their normal values. This was attributed to the ability of IB-MECA to induce the production of G-CSF (BarYehuda et al. 2002; Fishman et al. 2000b, 2001, 2002a, b, 2003; Hofer et al. 2006, 2007)

Overall, the unique characteristics of the $\mathrm{A}_{3} \mathrm{AR}$ agonists - they are orally bioavailable, exert their effects at low doses, enhance the effects of cytotoxic agents, and at the same time act as myeloprotective agents-together with their potential cardio- and neuroprotective activities suggest that this class of compounds may produce attractive clinical candidates as anticancer drugs.

\subsection{Mechanisms of Action for the Anticancer Activity of the $A_{3} A R$}

Adenosine receptors operate through distinct biochemical signaling mechanisms. The $\mathrm{A}_{1}$ and $\mathrm{A}_{3} \mathrm{AR}$ subtypes control most, if not all, of their cellular responses via pertussis toxinsensitive $G$ proteins of the $G_{i}$ and $G_{o}$ family. The $A_{3} A R$ triggers $G_{i}$-protein activation, induces an intracellular signaling cascade that increases intracellular calcium concentrations, activates PLC and phospholipase D (PLD) as well as the production of intracellular secondmessenger systems, which in turn, leads to related cellular responses such as cell proliferation or tumor cell apoptosis (Abbracchio et al. 1995; Murthy and Makhlouf 1995; Olah and Stiles 1995; Olah et al. 1995).

Activation of the $\mathrm{A}_{3} \mathrm{AR}$ inhibits adenylate cyclase activity, thereby leading to a decrease in the level of the second messenger, cAMP. The latter modulates the level and activity of protein kinase A (PKA) that phosphorylates downstream elements of the MAPK and protein kinase B (PKB)/Akt (PKB/Akt) signaling pathways (Poulsen and Quinn 1998; Seino and Shibasaki 2005; Zhao et al. 2000). In addition, it was reported that PKA phosphorylates 
$\mathrm{PKB} / \mathrm{Akt}$ directly, thereby mediating its activity (Fang et al. 2000). Both PKA and PKB/Akt regulate the NF- $\mathrm{KB}$ signaling pathway by phosphorylating and activating the downstream kinase I $\kappa$ B kinase (IKK), which phosphorylates I $k$ B, thereby sorting it to degradation via the ubiquitin system. As a result, NF- $\mathrm{kB}$ is released from its complex with I $\times \mathrm{B}$ and translocates to the nucleus to induce the transcription of genes such as cyclin D1 and $c$-Myc that control cell cycle progression (Karin and Ben-Neriah 2000; Li et al. 1999).

Taken together, since the activation of $\mathrm{A}_{3} \mathrm{AR}$ induces the inhibition of adenylate cylase and reduces the level of intracellular cAMP, the downstream elements PKA and PKB/Akt are not activated and so do not phosphorylate IKK. This leads to the reduced activity and expression levels of the NF- $\mathrm{KB}$, resulting in tumor cell cycle arrest and tumor growth inhibition.

\subsubsection{Direct Effect of $A_{3} A R$ Agonists on Tumor Cells: Deregulation of the NF- KB and Wnt Signaling Pathways-In melanoma, colon, prostate and hepatocellular} carcinoma cell lines, treatment with IB-MECA or Cl-IB-MECA produced a decrease in PKA and PKB/Akt expression (Bar-Yehuda et al. 2008; Fishman et al. 2002a, b, 2003, 2004). As a result, the phosphorylation of IKK was inhibited, leading to the accumulation of $\mathrm{I} \kappa \mathrm{B} / \mathrm{NF}-\kappa \mathrm{B}$ complex in the cytoplasm. This resulted in the downregulation of $c$-myc and cyclin D1 expression levels (Fig. 2) (Bar-Yehuda et al. 2008; Fishman et al. 2003, 2004).

Further studies showed that the Wnt signaling pathway is also involved in the anticancer activity mediated via the $A_{3} A R$. The rationale to investigate this pathway came from data showing that PKA and PKB/Akt phosphorylate and inactivate glycogen synthase kinase $3 \beta$ (GSK-3 $\beta$ ) (Cross et al. 1995; Fang et al. 2000). GSK-3 $\beta$ is a serine/threonine kinase that acts as a key element in the Wnt signaling pathway, which is known to play a pivotal role in dictating cell fate during embryogenesis and tumorigenesis (Peifer and Polakis 2000). GSK-3 $\beta$ phosphorylates the cytoplasmic protein $\beta$-catenin, which is sorted for degradation by the ubiquitin system. Upon phosphorylation, GSK-3 $\beta$ loses its ability to phosphorylate $\beta$ catenin, resulting in the accumulation of the latter in the cytoplasm and its subsequent translocation to the nucleus, where it associates with lymphoid enhancer factor/T-cell factor (Lef/Tcf) to induce the transcription of genes responsible for cell cycle progression, like $c$ myc and cyclin D1 (Fig. 2) (Ferkey and Kimelman 2000; Morin 1999; Novak and Dedhar 1999).

An inability of GSK-3 $\beta$ to phosphorylate $\beta$-catenin has been demonstrated in various malignancies, including colon carcinoma, melanoma and HCC (Bonvini et al. 1999; Cui et al. 2003; Robbins et al. 1996)

Treatment of B16-F10 melanoma, HCT-116 human colon carcinoma cells and PC-3 human prostate carcinoma cells in vitro with IB-MECA decreased PKA and PKB/Akt expression levels, resulting in the upregulation of GSK- $3 \beta$ and the subsequent phosphorylation and ubiquitination of $\beta$-catenin (Fishman et al. 2002a, 2003; Madi et al. 2003). In these studies, downregulation of cyclin D1 and $c$-myc expression levels, as well as tumor cell growth suppression, were observed (Fishman et al. 2002a, 2003; Madi et al. 2003). Moreover, the group of Lee et al. further reported that a highly specific $\mathrm{A}_{3} \mathrm{AR}$ agonist, thio-Cl-IB-MECA, induced apoptosis of HL-60 promyelocytic leukemia cells and lung cancer cells via deregulation of the Wnt signaling pathway. The levels of $\beta$-catenin, phosphorylated forms of GSK3- $\beta$ and Akt were downregulated upon treatment with thio-Cl-IB-MECA $(10 \mathrm{nM})$ in a time-dependent manner (Kim et al. 2008; Lee et al. 2005).

Additional evidence to support the in vitro mechanistic pathways presented above came from the analysis of tumor tissues excised from melanoma, prostate, colon and HCC tumor- 
bearing animals treated with IB-MECA or Cl-IB-MECA (Bar-Yehuda et al. 2008; Fishman et al. 2003, 2004; Madi et al. 2003).

Both the NF- $\kappa$ B and Wnt signal transduction pathways were deregulated upon treatment with the $\mathrm{A}_{3} \mathrm{AR}$ agonists, demonstrating a definitive molecular mechanism. Remarkably, $\mathrm{Cl}$ IB-MECA induced marked apoptosis of tumor cells in the N1S1 HCC-bearing rats (BarYehuda et al. 2008; Fishman et al. 2003, 2004; Madi et al. 2003).

In these studies, apoptosis of tumor cells was seen in the tunnel assay, and increases in the expression levels of the proapoptotic proteins Bad, BAX and capase 3 were observed as well (Bar-Yehuda et al. 2008; Fishman et al. 2003, 2004; Madi et al. 2003).

5.4.2 $\mathrm{A}_{3}$ AR Agonists as Myeloprotective Agents-Some chemotherapeutic agents are known to induce myelosuppression, as manifested by a decline in the number of white blood cells (especially neutrophils), making patients susceptible to infections and sepsis. GCSF is a hematopoietic growth factor produced by endothelium, macrophages, and a number of other immune cells, and its synthesis is induced by activation of the transcription factor NF- $\kappa$ B. It stimulates the proliferation and differentiation of white blood cells. A recombinant form of G-CSF has become a standard supportive therapy for cancer patients to accelerate recovery from neutropenia after chemotherapy (Brandt et al. 1988; Rusthoven et al. 1998). In mice, IB-MECA induces G-CSF production and increases white blood cell and neutrophil counts in naïve and chemotherapy-treated animals (Bar-Yehuda et al. 2002). The myelostimulative effect of IB-MECA was also evidenced by high levels of G-CSF in bone marrow cells, splenocytes, and serum derived from IB-MECA-treated mice. Moreover, in splenocytes derived from IB-MECA-treated mice, increased expression levels of phosphoinositide 3-kinase (PI3K), known to play a role in the regulation of cell survival and proliferation (Gao et al. 2001), was noted. Consequently, the expression levels of PKB/Akt, IKK and NF- $\kappa$ B were enhanced, resulting in G-CSF upregulation (Fig. 3).

The role of the $\mathrm{A}_{3} \mathrm{AR}$ and PI3K-NF- $\kappa \mathrm{B}$ pathway in the production of G-CSF was further confirmed by treating the mice with pertussis toxin, a $\mathrm{G}_{i}$-protein inactivator that interferes with the coupling of the receptor to the $G_{i}$ protein. Splenocytes derived from mice that were treated with IB-MECA and pertussis toxin did not up-regulate NF- $\kappa \mathrm{B}$ levels. Moreover, the $\mathrm{NF}-\kappa \mathrm{B}$ inhibitor pyrrolidine dithiocarbamate (PDTC), known to suppress the release of $\mathrm{I} \kappa \mathrm{B}$ from the latent cytoplasmic form of NF- $\kappa \mathrm{B}$, counteracted the effect of IB-MECA and prevented the increase in NF- $\kappa$ B expression levels (Bar-Yehuda et al. 2002).

Taken together with the studies described in Sect. 5.4.1 above, these studies suggest that activation of the $\mathrm{A}_{3} \mathrm{AR}$ by specific agonists induces differential effects on normal and tumor cells to produce modulations of definitive signal transduction pathways that control cell growth regulatory mechanisms in the case of tumor cells and growth factor production in the case of normal hematopoietic cells (e.g., bone marrow cells and splenocytes).

\section{Anticancer Activity of $A_{3} A R$ Antagonists}

A very interesting area of application of $\mathrm{A}_{3} \mathrm{AR}$ ligands concerns cancer therapies. The possibility that the $\mathrm{A}_{3} \mathrm{AR}$ plays an important role in the development of cancer has aroused considerable interest in recent years (Fishman et al. 2002b; Gessi et al. 2008; Merighi et al. 2003). The $A_{3} A R$ subtype has been described in the regulation of the cell cycle, and both pro- and antiapoptotic effects have been reported, depending on the level of receptor activation (Gao et al. 2001; Gessi et al. 2007; Jacobson 1998; Merighi et al. 2005a; Yao et al. 1997). However, based on the studies presented above, it is important to note that $\mathrm{A}_{3} \mathrm{AR}$ 
receptor activation appears to be involved in the inhibition of tumor growth both in vitro and in vivo.

Based on the relationships between tumors, hypoxia and adenosine concentrations, there are reports describing the potential utility of $\mathrm{A}_{3} \mathrm{AR}$ antagonists for cancer treatment. Growing evidence from experimental and clinical studies points to the fundamental pathophysiological role of hypoxia in solid tumors. Hypoxia is the result of an imbalance between oxygen supply and consumption. Clinical investigations carried out over the last 15 years have clearly shown that the prevalence of hypoxic tissue areas is a characteristic pathophysiological feature of solid tumors. As the oxygen concentration decreases with increasing distance from the capillary, cell proliferation rates and drug concentrations both decrease. These two factors lead to resistance to anticancer drugs; firstly, because the majority of anticancer drugs are only effective against rapidly proliferating cells; secondly, because adequate levels of chemotherapy drugs have to reach the tumor cells from the blood vessels. Hypoxia inhibits enzymes that are involved in the breakdown of adenosine and increases the activities of those responsible for generating adenosine, thereby resulting in an increase in extracellular and intracellular adenosine. The elevated adenosine levels in response to hypoxia are not exclusive to tumor tissues, but, in this context, the increase in adenosine is localized to the tumor microenvironment, since the surrounding tissue is normally oxygenated (Blay et al. 1997). To survive under hypoxic conditions, tumor cells run numerous adaptive mechanisms, such as glycolysis, glucose uptake, and survival factor upregulation (Hockel and Vaupel 2001). Hypoxia-inducible factor (HIF) 1 is the most important factor involved in the cellular response to hypoxia (Semenza 2003). It is a heterodimer composed of an inducibly expressed HIF-1a subunit and a constitutively expressed HIF-1 $\beta$ subunit (Epstein et al. 2001). HIF-1a and HIF-1 $\beta$ mRNAs are constantly expressed under normoxic and hypoxic conditions (Wiener et al. 1996). However, during normoxia, HIF-1a is rapidly degraded by the ubiquitin proteasome system, whereas exposure to hypoxic conditions prevents its degradation (Minchenko et al. 2002; Semenza 2000). HIF-1a expression and activity are also regulated by the PI3K and MAPK signal transduction pathways (Semenza 2002; Zhong et al. 2000). A growing body of evidence indicates that HIF-1a contributes to tumor progression and metastasis (Hopfl et al. 2004; Welsh and Powis 2003). Immunohistochemical analyses have shown that HIF-1a is present in higher levels in human tumors than in normal tissues (Zhong et al. 1999), and the levels of HIF-1a activity in cells correlate with the tumorigenicity and angiogenesis in nude mice (Carmeliet et al. 1998). Tumor cells lacking HIF-1a expression are markedly impaired in their growth and vascularization (Jiang et al. 1997; Kung et al. 2000; Maxwell et al. 1997). Therefore, since HIF-1a expression and activity appear central to tumor growth and progression, HIF-1a inhibition becomes an appropriate approach to treating cancer (Kung et al. 2000; Ratcliffe et al. 2000; Semenza 2003). Hypoxia creates conditions that, on the one hand, are conducive to the accumulation of extracellular adenosine, and on the other hand stabilize hypoxia-inducible factors, such as HIF-1a (Fredholm 2003; Hockel and Vaupel 2001; Linden 2001; Minchenko et al. 2002; Semenza 2000; Sitkovsky et al. 2004). In particular, the correlation between AR stimulation and HIF-1a expression modulation in hypoxia has recently been investigated. It has been reported that adenosine increases HIF-1a protein accumulation in response to hypoxia in a dose- and time-dependent manner in human melanoma, glioblastoma and colon carcinoma through the involvement of the cell surface $A_{3} A R$ (Merighi et al. 2005b, 2006, 2007). The signaling pathway involved in $\mathrm{A}_{3} \mathrm{AR}$-mediated accumulation of HIF-1a in hypoxia involves MAPKinase activity (Merighi et al. 2005b, 2006, 2007). It is well established that HIF-1a plays a major role in VEGF expression and angiogenesis. Furthermore, there is strong evidence that adenosine released from hypoxic tissues is an important player in driving the angiogenesis, by enhancing vascular growth through various mechanisms including the release of different factors, with VEGF being one of the most relevant (Adair 2005). A role for $A_{2 B} A R s$ in angiogenesis 
through an HIF-1a -independent intracellular pathway has been observed in human endothelial and smooth muscle cells (Feoktistov et al. 2004), but involvement of HIF-1a with the $\mathrm{A}_{3} \mathrm{AR}$ has been demonstrated in different cancer cell lines (Merighi et al. 2005b, 2006, 2007). In particular, activation of the $A_{3} A R$ subtype in glioblastoma and colon carcinoma cells stimulates VEGF expression in an HIF-1a-dependent manner (Merighi et al. 2006, 2007). In addition, $A_{3} A R$ activation results in increased expression of another angiogenic factor, angiopoietin 2, in melanoma cells and HMC-1 cells derived from a highly malignant, undifferentiated human mastocytoma cancer (Feoktistov et al. 2003; Merighi et al. 2005b). This may be relevant because the effect of adenosine on new capillary formation is potentiated by the concomitant stimulation of $\mathrm{A}_{2 \mathrm{~B}} \mathrm{ARs}$ and $\mathrm{A}_{3} \mathrm{ARs}$ acting on VEGF and angiopoietin 2 levels, respectively (Feoktistov et al. 2003). Recent studies indicate that pharmacologic inhibition of HIF-1a and particularly of HIF-regulated genes, which are important for cancer cell survival, may be more advantageous than HIF-gene-inactivation therapeutic approaches (Mabjeesh et al. 2003; Merighi et al. 2005b; Sitkovsky et al. 2004). In this regard, by blocking hypoxia-induced increases in HIF-1a, angiopoietin 2 and VEGF protein expression in the tumor microenvironment, $\mathrm{A}_{3} \mathrm{AR}$ antagonists may represent a novel approach to the treatment of cancer.

\section{Summary and Conclusions}

Adenosine, the natural ligand of the four AR subtypes, affects all of these receptors under neoplastic conditions due to its mass accumulation in the tumor microenvironment. Its role in maintaining pro- and anticancer effects via each of its receptor subtypes was extensively reviewed in this chapter. Based on the studies presented in this review, it appears that all the AR subtypes are possible targets for the development of novel approaches to the treatment of cancer.

The antitumorigenic role of $A_{1} A R$ in cancer was mainly studied in $A_{1} A R$-deficient mice, demonstrating that activation of the $\mathrm{A}_{1} \mathrm{AR}$ on microglia inhibits the growth of glioblastomas.

Based on a number of reports, it has been suggested that the $\mathrm{A}_{2 \mathrm{~A}} \mathrm{AR}$ blocks antitumor immunity. In the tumor environment of hypoxia and high adenosine levels, activation of $\mathrm{A}_{2 \mathrm{~A}} \mathrm{ARs}$ leads to $\mathrm{T}$-cell tolerance, inhibition of effector immune cells (including $\mathrm{T}$ cells, CTLs, NK cells, dendritic cells, and macrophages), an increase in regulatory T cells, and a decrease in proinflammatory cytokines, all of which thwart antitumor immunity and thus encourage tumor growth. Importantly, $\mathrm{A}_{2 \mathrm{~A}} \mathrm{AR}$-null mice have been shown to more readily reject melanoma and lymphoma tumor challenge and to also respond to vaccines. Moreover, treating mice with $\mathrm{A}_{2 \mathrm{~A}} \mathrm{AR}$ antagonists (including caffeine) leads to increased tumor rejection by $\mathrm{CD} 8+\mathrm{T}$ cells. For all these reasons, it was suggested that the addition of $\mathrm{A}_{2 \mathrm{~A}} \mathrm{AR}$ antagonists to cancer immunotherapeutic protocols may enhance tumor immunotherapy. Interestingly, the safety of such compounds has already been shown in trials employing $\mathrm{A}_{2 \mathrm{~A}} \mathrm{AR}$ antagonists for the treatment of Parkinson's disease.

The role of the $A_{2 B} A R$ in cancer is not clear. On the one hand, under conditions of hypoxia and high adenosine levels in the tumor microenvironment, activation of $\mathrm{A}_{2 \mathrm{~B}} \mathrm{ARs}$ leads to the release of angiogenic factors that promote tumor growth, suggesting that the use of $\mathrm{A}_{2 \mathrm{~B}} \mathrm{AR}$ antagonists may represent a novel approach to the treatment of cancer. On the other hand, the activation of $\mathrm{A}_{2 \mathrm{~B}} \mathrm{ARs}$ exclusively expressed on the surface of breast cancer cell line MDA-MB-231 cells exerts an inhibitory signal mediated via the inhibition of ERK 1/2 phosphorylation, suggesting that $\mathrm{A}_{2 \mathrm{~B}} \mathrm{AR}$ agonists may produce anticancer effects. The resolution of this dilemma will initially come from testing selective ligands for the $A_{2 B} A R$ 
in in vitro and in vivo studies in various cancer cell lines and tumor-bearing animals, and then, depending on the results of these studies, perhaps in humans with cancer.

The unique characteristics of the $\mathrm{A}_{3} \mathrm{ARs}$ that are highly expressed in tumor cells suggest that this receptor subtype is an attractive target to combat cancer. Targeting the $\mathrm{A}_{3} \mathrm{AR}$ with synthetic agonists results in cell cycle arrest and apoptosis towards different cancer cells both in vitro and in vivo. Preclinical and Phase I studies show that these agonists are safe and well tolerated in humans and thus may be considered possible therapeutic agents for certain neoplasmas such as HCC, where a significant apoptotic effect was demonstrated. However, by blocking hypoxia-induced increases in HIF-1a, angiopoietin 2 and VEGF protein expression in the tumor microenvironment, $\mathrm{A}_{3} \mathrm{AR}$ antagonists may represent a novel approach for the treatment of cancer.

\section{Abbreviations}

\begin{tabular}{|c|c|}
\hline $\mathbf{A}_{1} \mathrm{AR}$ & $\mathrm{A}_{1}$ adenosine receptor \\
\hline $\mathbf{A}_{2 \mathbf{A}} \mathbf{A R}$ & $\mathrm{A}_{2 \mathrm{~A}}$ adenosine receptor \\
\hline $\mathbf{A}_{2 B} \mathbf{A R}$ & $\mathrm{A}_{2 \mathrm{~B}}$ adenosine receptor \\
\hline $\mathbf{A}_{\mathbf{3}} \mathbf{A R}$ & $\mathrm{A}_{3}$ adenosine receptor \\
\hline APCs & Antigen-presenting cells \\
\hline $\mathbf{A R}$ & Adenosine receptor \\
\hline bFGF & Basic fibroblast growth factor \\
\hline CCPA & 2-Chloro- $N^{6}$-cyclopentyladenosine \\
\hline CD39 & Cluster of differentiation 39 \\
\hline CD73 & Cluster of differentiation 73 \\
\hline GGAP & Cancer Genome Anatomy Project \\
\hline CGS21680 & $\begin{array}{l}\text { 2- } p \text {-(2-Carboxyethyl)phenethylamino- } 5^{\prime} \text { - } N \text {-ethylcarbox } \\
\text { amidoadenosine } 1680\end{array}$ \\
\hline CHO & Chinese hamster ovary cells \\
\hline Cl-IB-MECA & 2-Chloro- $N^{6}$-3-iodobenzyladenosine- $5^{\prime}-N$-methyluronamide \\
\hline CNS & Central nervous system \\
\hline CPA & $N^{6}$-Cyclopentyladenosine \\
\hline CTLA-4 & Cytotoxic T lymphocyte-associated antigen 4 \\
\hline CTLs & Cytotoxic T lymphocytes \\
\hline DPCPX & 8-Cyclopentyl-1,3-dipropylxanthine \\
\hline EGF & Epidermal growth factor \\
\hline Epac & Exchange protein activated by cAMP \\
\hline ER & Estrogen receptor \\
\hline ERK & Extracellular signal-regulated kinase \\
\hline G-CSF & Granulocyte colony stimulating factor \\
\hline GPCR & G-protein-coupled receptor \\
\hline GSK-3 $\beta$ & Glycogen synthase kinase $3 \beta$ \\
\hline
\end{tabular}




\begin{tabular}{|c|c|}
\hline HA & Hyaluronan \\
\hline HCC & Hepatocellular carcinoma \\
\hline HIF-1 & Hypoxia-inducible factor 1 \\
\hline HMG1b & High mobility group $1 \mathrm{~b}$ \\
\hline HUGO & Human Genome Organization \\
\hline IB-MECA & Methyl 1-[ $N^{6}$-(3-iodobenzyl)-adenin-9-yl]- $\beta$-D-ribofuronamid \\
\hline IKK & I $\kappa \mathrm{B}$ kinase \\
\hline IL & Interleukin \\
\hline Lef/Tcf & Lymphoid enhancer factor/T-cell factor \\
\hline MAP & Mitogen-activated protein \\
\hline MMP & Metalloproteinase \\
\hline MRS1191 & $\begin{array}{l}\text { 3-Ethyl-5-benzyl-2-methyl-4-phenylethynyl-6-phenyl-1,4-( } \pm \text {-) } \\
\text { dihydropyridine-3,5-dicarboxylate }\end{array}$ \\
\hline MTT & 1-(4,5-Dimethylthiazol-2-yl)-3,5-diphenylformazan thiazolyl \\
\hline NECA & Adenosine- $5^{\prime}-N$-ethyluronamide \\
\hline $\mathbf{N F}-x \mathbf{B}$ & Nuclear factor kappa B \\
\hline NK & Natural killers \\
\hline PAMPs & Pathogen-associated molecular patterns \\
\hline PARP & Poly(ADP-ribose) polymerase \\
\hline PBMCs & Peripheral blood mononuclear cells \\
\hline PDTC & Pyrrolidine dithiocarbamate \\
\hline PI3K & Phosphoinositide 3-kinase \\
\hline PKA & Protein kinase A \\
\hline PKB & Protein kinase B \\
\hline PKB/Akt & Protein kinase B/Akt \\
\hline PLC & Phospholipase C \\
\hline PLD & Phospholipase D \\
\hline TCR & T-cell receptor \\
\hline TGF- $\beta$ & Transforming growth factor $\beta$ \\
\hline thio-Cl-IB-MECA & $\begin{array}{l}\text { 2-Chloro- } N^{6} \text {-(3-iodobenzyl)- } 4^{\prime} \text {-thioadenosine- } 5^{\prime}-N \text { - } \\
\text { methyluronamide }\end{array}$ \\
\hline TNF- $a$ & Tumor necrosis factor \\
\hline VEGF & Vascular endothelial growth factor \\
\hline Wt & Wild type \\
\hline
\end{tabular}




\section{References}

Abbracchio MP, Brambilla R, Ceruti S, Kim HO, von Lubitz DK, Jacobson KA, Cattabeni F. G protein-dependent activation of phospholipase $\mathrm{C}$ by adenosine $\mathrm{A}_{3}$ receptors in rat brain. Mol Pharmacol. 1995; 48:1038-1045. [PubMed: 8848003]

Abbracchio MP, Rainaldi G, Giammarioli AM, Ceruti S, Brambilla R, Cattabeni F, Barbieri D, Franceschi C, Jacobson KA, Malorni W. The $\mathrm{A}_{3}$ adenosine receptor mediates cell spreading, reorganization of actin cytoskeleton, and distribution of Bcl-XL: studies in human astroglioma cells. Biochem Biophys Res Commun. 1997; 241:297-304. [PubMed: 9425266]

Abbracchio MP, Camurri A, Ceruti S, Cattabeni F, Falzano L, Giammarioli AM, Jacobson KA, Trincavelli L, Martini C, Malorni W, Fiorentini C. The $\mathrm{A}_{3}$ adenosine receptor induces cytoskeleton rearrangement in human astrocytoma cells via a specific action on Rho proteins. Ann N Y Acad Sci. 2001; 939:63-73. [PubMed: 11462805]

Adair TH. Growth regulation of the vascular system: an emerging role for adenosine. Am J Physiol Regul Integr Comp Physiol. 2005; 289:R283-R296. [PubMed: 16014444]

Auchampach JA, Xiaowei J, Tina CW, George H, Caughey GH, Linden J. Canine mast cell adenosine receptors: cloning and expression of the $\mathrm{A}_{3}$ receptor and evidence that degranulation is mediated by the A2B receptor. Mol Pharmacol. 1997; 52:846-860. [PubMed: 9351976]

Bar-Yehuda S, Barer F, Volfsson L, Fishman P. Resistance of muscles to tumor metastasis: a role for $\mathrm{A}_{3}$ adenosine receptor agonists. Neoplasia. 2001; 3:125-131. [PubMed: 11420748]

Bar-Yehuda S, Madi L, Barak D, Mittelman M, Ardon E, Ochaion A, Cohn S, Fishman P. Agonists to the $\mathrm{A}_{3}$ adenosine receptor induce G-CSF production via NF-kappaB activation: a new class of myeloprotective agents. Exp Hematol. 2002; 30:1390-1398. [PubMed: 12482500]

Bar-Yehuda S, Madi L, Silberman D, Slosman G, Shkapenuk M, Fishman P. CF101, an agonist to the $\mathrm{A}_{3}$ adenosine receptor enhances the chemotherapeutic effect of 5-flurouracil in a colon carcinoma murine model. Neoplasia. 2005; 7:85-90. [PubMed: 15720820]

Bar-Yehuda S, Silverman MH, Kerns WD, Ochaion A, Cohen S, Fishman P. The anti-inflammatory effect of $\mathrm{A}_{3}$ adenosine receptor agonists: a novel targeted therapy for rheumatoid arthritis. Expert Opin Invest Drugs. 2007; 16:1601-1613.

Bar-Yehuda S, Stemmer SM, Madi L, Castel D, Ochaion A, Cohen S, Barer F, Zabutti A, Perez-Liz G, Del Valle L, Fishman P. The $\mathrm{A}_{3}$ adenosine receptor agonist CF102 induces apoptosis of hepatocellular carcinoma via de-regulation of the Wnt and NF- $\mathrm{BB}$ signal transduction pathways. Int J Oncol. 2008; 33:287-295. [PubMed: 18636149]

Barry CP, Lind SE. Adenosine-mediated killing of cultured epithelial cancer cells. Cancer Res. 2000; 60:1887-1894. [PubMed: 10766176]

Bianchi L, De Micheli E, Bricolo A, Ballini C, Fattori M, Venturi C, Pedata F, Tipton KF, Della Corte L. Extracellular levels of amino acids and choline in human high grade gliomas: an intraoperative microdialysis study. Neurochem Res. 2004; 29:325-334. [PubMed: 14992293]

Bieber D, Lorenz K, Yadav R, Klotz K-N. A2B adenosine receptors mediate an inhibition of ERK 1/2 phosphorylation in the breast cancer cell line MDA-MB-231. Naunyn-Schmiedeberg's Arch Pharmacol. 2008; 377(Suppl 1):19.

Blank C, Mackensen A. Contribution of the PD-L1/PD-1 pathway to T-cell exhaustion: an update on implications for chronic infections and tumor evasion. Cancer Immunol Immunother. 2007; 56:739-745. [PubMed: 17195077]

Blay J, White TD, Hoskin DW. The extracellular fluid of solid carcinomas contains immunosuppressive concentrations of adenosine. Cancer Res. 1997; 57:2602-2605. [PubMed: 9205063]

Bonvini P, Hwang SG, el-Gamil M, Robbins P, Neckers L, Trepel J. Melanoma cell lines contain a proteasome-sensitive, nuclear cytoskeleton-associated pool of beta-catenin. Ann N Y Acad Sci. 1999; 886:208-211. [PubMed: 10667221]

Brandt SJ, Peters WP, Atwater SK, Kurtzberg J, Borowitz MJ, Jones RB, Shpall EJ, Bast RC Jr, Gilbert CJ, Oette DH. Effect of recombinant human granulocyte-macrophage colony-stimulating factor on hematopoietic reconstitution after high-dose chemotherapy and autologous bone marrow transplantation. N Engl J Med. 1988; 318:869-876. [PubMed: 3281007] 
Braun N, Sévigny J, Robson SC, Enjyoji K, Guckelberger O, Hammer K, Di Virgilio F, Zimmermann $\mathrm{H}$. Assignment of ecto-nucleoside triphosphate diphosphohydrolase-1/cd39 expression to microglia and vasculature of the brain. Eur J Neurosci. 2000; 12:4357-4366. [PubMed: 11122346]

Bunemann M, Lee KB, Pals-Rylaarsdam R, Roseberry AG, Hosey MM. Desensitization of G-proteincoupled receptors in the cardiovascular system. Annu Rev Physiol. 1999; 61:169-192. [PubMed: 10099686]

Burnstock G. Purinergic signaling: an overview. Novartis Found Symp. 2006; 276:26-48. [PubMed: 16805422]

Carmeliet P, Dor Y, Herbert JM. HIF-1alpha in hypoxia-mediated apoptosis, cell proliferation and tumour angiogenesis. Nature. 1998; 394:485-490. [PubMed: 9697772]

Chen GJ, Harvey BK, Shen H, Chou J, Victor A, Wang Y. Activation of adenosine $\mathrm{A}_{3}$ receptors reduces ischemic brain injury in rodents. J Neurosci Res. 2006; 84:1848-1855. [PubMed: 17016854]

Chung H, Jung J-Y, Cho S-D, Hong K-A, Kim H-J, Shin D-H, Kim H, Kim HO, Shin DH, Lee HW, Jeong LS, Kong G. The antitumor effect of LJ-529, a novel agonist to $\mathrm{A}_{3}$ adeno-sine receptor, in both estrogen receptor-positive and estrogen receptor-negative human breast cancers. Mol Cancer Ther. 2006; 5:685-692. [PubMed: 16546983]

Claing A, Laporte SA, Caron MG, Lefkowitz RJ. Endocytosis of G protein-coupled receptors: roles of $\mathrm{G}$ protein-coupled receptor kinases and beta-arrestin proteins. Prog Neurobiol. 2002; 66:61-79. [PubMed: 11900882]

Cristalli G, Lambertucci C, Taffi S, Vittori S, Volpini R. Medicinal chemistry of adenosine $\mathrm{A}_{2 \mathrm{~A}}$ receptor agonists. Curr Top Med Chem. 2003; 3:387-401. [PubMed: 12570757]

Cross DA, Alessi DR, Cohen P, Andjelkovich M, Hemmings BA. Inhibition of glycogen synthase kinase-3 by insulin mediated by protein kinase B. Nature. 1995; 378:785-789. [PubMed: 8524413]

Cui J, Zhou X, Liu Y, Tang Z, Romeih M. Wnt signaling in hepatocellular carcinoma: analysis of mutation and expression of beta-catenin, T-cell factor-4 and glycogen synthase kinase 3-beta genes. J Gastroenterol Hepatol. 2003; 18:280-287. [PubMed: 12603528]

Deaglio S, Dwyer KM, Gao W, Friedman D, Usheva A, Erat A, Chen JF, Enjyoji K, Linden J, Oukka M, Kuchroo VK, Strom TB, Robson SC. Adenosine generation catalyzed by CD39 and CD73 expressed on regulatory T-cells mediates immune suppression. J Exp Med. 2007; 204:1257-1265. [PubMed: 17502665]

Dhillon AS, Hagan S, Rath O, Kolch W. MAP kinase signalling pathways in cancer. Onco-gene. 2007; 26:3279-3290.

Drake CG, Jaffee E, Pardoll DM. Mechanisms of immune evasion by tumors. Adv Immunol. 2006; 90:51-81. [PubMed: 16730261]

Dubey RK, Gillespie DG, Shue H, Jackson EK. A2B receptors mediate antimitogenesis in vascular smooth muscle cells. Hypertension. 2000; 35:267-272. [PubMed: 10642309]

Dunwiddie TV. The physiological role of adenosine in the central nervous system. Int Rev Neurobiol. 1985; 27:63-139. [PubMed: 2867982]

Egen JG, Kuhns MS, Allison JP. CTLA-4: new insights into its biological function and use in tumor immunotherapy. Nat Immunol. 2002; 3:611-618. [PubMed: 12087419]

Epstein AC, Gleadle JM, McNeill LA, Hewitson KS, O'Rourke J, Mole DR, Mukherji M, Metzen E, Wilson MI, Dhanda A, Tian YM, Masson N, Hamilton DL, Jaakkola P, Barstead R, Hodgkin J, Maxwell PH, Pugh CW, Schofield CJ, Ratcliffe PJ. C. elegans EGL-9 and mammalian homologs define a family of dioxygenases that regulate HIF by prolyl hydroxylation. Cell. 2001; 107:43-54. [PubMed: 11595184]

Erdmann AA, Gao ZG, Jung U, Foley J, Borenstein T, Jacobson KA, Fowler DH. Activation of Th1 and $\mathrm{Tc} 1$ cell adenosine $\mathrm{A}_{2 \mathrm{~A}}$ receptors directly inhibits IL-2 secretion in vitro and IL-2-driven expansion in vivo. Blood. 2005; 105:4707-4714. [PubMed: 15746085]

Fang X, Yu SX, Lu Y, Bast RC Jr, Woodgett JR, Mills GB. Phosphorylation and inactivation of glycogen synthase kinase 3 by protein kinase A. Proc Natl Acad Sci USA. 2000; 24:11960-11965. [PubMed: 11035810] 
Farber K, Kettenmann H. Purinergic signaling and microglia. Pflugers Arch. 2006; 452:615-621. [PubMed: 16791619]

Färber K, Markworth S, Pannasch U, Nolte C, Prinz V, Kronenberg G, Gertz K, Endres M, Bechmann I, Enjyoji K, Robson SC, Kettenmann H. The ectonucleotidase cd39/ENTPDase1 modulates purinergic-mediated microglial migration. Glia. 2008; 56:331-341. [PubMed: 18098126]

Feoktistov I, Murray JJ, Biaggioni I. Positive modulation of intracellular $\mathrm{Ca}^{2+}$ levels by adenosine A2B receptors, prostacyclin, and prostaglandin E1 via a cholera toxin-sensitive mechanism in human erythroleukemia cells. Mol Pharmacol. 1994; 45:1160-1167. [PubMed: 8022409]

Feoktistov I, Goldstein AE, Ryzhov S, Zeng D, Belardinelli L, Voyno-Yasenetskaya T, Biaggioni I. Differential expression of adenosine receptors in human endothelial cells: role of $\mathrm{A}_{2 \mathrm{~B}}$ receptors in angiogenic factor regulation. Circ Res. 2002; 90:531-538. [PubMed: 11909816]

Feoktistov I, Ryzhov S, Goldstein AE, Biaggioni I. Mast cell-mediated stimulation of angio-genesis: cooperative interaction between $\mathrm{A}_{2 \mathrm{~B}}$ and $\mathrm{A}_{3}$ adenosine receptors. Circ Res. 2003; 92:485-492. [PubMed: 12600879]

Feoktistov I, Ryzhov S, Zhong H, Goldstein AE, Matafonov A, Zeng D, Biaggioni I. Hypoxia modulates adenosine receptors in human endothelial and smooth muscle cells toward an $\mathrm{A}_{2 \mathrm{~B}}$ angiogenic phenotype. Hypertension. 2004; 44:649-654. [PubMed: 15452028]

Ferkey DM, Kimelman D. GSK-3: new thoughts on an old enzyme. Dev Biol. 2000; 225:471-479. [PubMed: 10985864]

Fiebich BL, Biber K, Lieb K, van Calker D, Berger M, Bauer J, Gebicke-Haerter PJ. Cyclooxygenase-2 expression in rat microglia is induced by adenosine $\mathrm{A}_{2 \mathrm{a}}$-receptors. Glia. 1996; 18:152-160. [PubMed: 8913778]

Fields RD, Burnstock G. Purinergic signalling in neuron-glia interactions. Nat Rev Neurosci. 2006; 7:423-436. [PubMed: 16715052]

Fishman P, Bar-Yehuda S, Ohana G, Pathak S, Wasserman L, Barer F, Multani AF. Adenosine acts as an inhibitor of lymphoma cell growth: a major role for the $\mathrm{A}_{3}$ adenosine receptor. Eur J Cancer. 2000a; 36:1452-1458. [PubMed: 10899660]

Fishman P, Bar-Yehuda S, Farbstein T, Barer F, Ohana G. Adenosine acts as a chemoprotective agent by stimulating G-CSF production: a role for $\mathrm{A}_{1}$ and $\mathrm{A}_{3}$ adenosine receptors. J Cell Physiol. 2000b; 183:393-398. [PubMed: 10797314]

Fishman P, Bar-Yehuda S, Barer F, Madi L, Multani AF, Pathak S. The $\mathrm{A}_{3}$ adenosine receptor as a new target for cancer therapy and chemoprotection. Exp Cell Res. 2001; 269:230-236. [PubMed: 11570815]

Fishman P, Madi L, Bar-Yehuda S, Barer F, Del Valle L, Khalili K. Evidence for involvement of Wnt signaling pathway in IB-MECA mediated suppression of melanoma cells. Oncogene. 2002a; 21:4060-4064. [PubMed: 12037688]

Fishman P, Bar-Yehuda S, Madi L, Cohn I. A 3 adenosine receptor as a target for cancer therapy. Anticancer Drugs. 2002b; 13:1-8. [PubMed: 11914636]

Fishman P, Bar-Yehuda S, Rath-Wolfson L, Ardon E, Barrer F, Ochaion A, Madi L. Targeting the $\mathrm{A}_{3}$ adenosine receptor for cancer therapy: inhibition of prostate carcinoma cell growth by $\mathrm{A}_{3} \mathrm{AR}$ agonist. Anticancer Res. 2003; 23:2077-2083. [PubMed: 12894581]

Fishman P, Bar-Yehuda S, Ohana G, Ochaion A, Engelberg A, Barer F, Madi L. An agonist to the $\mathrm{A}_{3}$ adenosine receptor inhibits colon carcinoma growth in mice via modulation of GSK-3 $\beta$ and NFкB. Oncogene. 2004; 23:2465-2471. [PubMed: 14691449]

Fishman P, Jacobson KA, Ochaion A, Cohen S, Bar-Yehuda S. The anti-cancer effect of $\mathrm{A}_{3}$ adenosine receptor agonists: a novel targeted therapy. Immunol Endocr Metab Agents Med Chem. 2007; 7:298-303.

Fredholm BB. Adenosine and neuroprotection. Int Rev Neurobiol. 1997; 40:259-280. [PubMed: 8989624]

Fredholm BB. Adenosine receptors as targets for drug development. Drug News Perspect. 2003; 16:283-289. [PubMed: 12942159]

Fredholm BB, Irenius E, Kull B, Schulte G. Comparison of the potency of adenosine as an agonist at human adenosine receptors expressed in Chinese hamster ovary cells. Biochem Pharmacol. 2001; 61:443-448. [PubMed: 11226378] 
Fredholm BB, Chen JF, Masino SA, Vaugeois JM. Actions of adenosine at its receptors in the CNS: insights from knockouts and drugs. Annu Rev Pharmacol Toxicol. 2005; 45:385-412. [PubMed: 15822182]

Gao Z, Li BS, Day YJ, Linden J. A 3 adenosine receptor activation triggers phosphorylation of protein kinase B and protects rat basophilic leukemia $2 \mathrm{H} 3$ mast cells from apoptosis. Mol Pharmacol. 2001; 59:76-82. [PubMed: 11125027]

Gao ZG, Kim SK, Biadatti T, Chen W, Lee K, Barak D, Kim SG, Johnson CR, Jacobson KA. Structural determinants of A(3) adenosine receptor activation: nucleoside ligands at the agonist/ antagonist boundary. J Med Chem. 2002; 45:4471-4484. [PubMed: 12238926]

Gebicke-Haerter PJ, Christoffel F, Timmer J, Northoff H, Berger M, Van Calker D. Both adenosine $\mathrm{A}_{1}$ - and $\mathrm{A}_{2}$-receptors are required to stimulate microglial proliferation. Neurochem Int. 1996; 29:37-42. [PubMed: 8808787]

Gessi S, Varani K, Merighi S, Cattabriga E, Iannotta V, Leung E, Baraldi PG, Borea PA. A(3) adenosine receptors in human neutrophils and promyelocytic HL60 cells: a pharmacological and biochemical study. Mol Pharmacol. 2002; 61:415-424. [PubMed: 11809867]

Gessi S, Cattabriga E, Avitabile A, Gafa' R, Lanza G, Cavazzini L, Bianchi N, Gambari R, Feo C, Liboni A, Gullini S, Leung E, Mac-Lennan S, Borea PA. Elevated expression of $\mathrm{A}_{3}$ adenosine receptors in human colorectal cancer is reflected in peripheral blood cells. Clin Cancer Res. 2004; 10:5895-5901. [PubMed: 15355922]

Gessi S, Merighi S, Varani K, Cattabriga E, Benini A, Mirandola P, Leung E, Mac Lennan S, Feo C, Baraldi S, Borea PA. Adenosine receptors in colon carcinoma tissues and colon tumoral cell lines: focus on the $\mathrm{A}_{3}$ adenosine subtype. J Cell Physiol. 2007; 211:826-836. [PubMed: 17348028]

Gessi S, Merighi S, Varani K, Leung E, Mac Lennan S, Borea PA. The $\mathrm{A}_{3}$ adenosine receptor: an enigmatic player in cell biology. Pharmacol Ther. 2008; 117:123-140. [PubMed: 18029023]

Giménez-Llort L, Fernández-Teruel A, Escorihuela RM, Fredholm BB, Tobeña A, Pekny M, Johansson $\mathrm{B}$. Mice lacking the adenosine $\mathrm{A}_{1}$ receptor are anxious and aggressive, but are normal learners with reduced muscle strength and survival rate. Eur J Neurosci. 2002; 16:547-550. [PubMed: 12193199]

Glass R, Synowitz M, Kronenberg G, Walzlein JH, Markovic DS, Wang LP, Gast D, Kiwit J, Kempermann G, Kettenmann H. Glioblastoma-induced attraction of endogenous neural precursor cells is associated with improved survival. J Neurosci. 2005; 25:2637-2646. [PubMed: 15758174]

Goldsmith ZG, Dhanasekaran DN. G Protein regulation of MAPK networks. Oncogene. 2007; 26:3122-3142. [PubMed: 17496911]

Graham S, Combes P, Crumiere M, Klotz K-N, Dickenson JM. Regulation of P42/P44 mitogenactivated protein kinase by the human adenosine $\mathrm{A}_{3}$ receptor in transfected $\mathrm{CHO}$ cells. Eur $\mathrm{J}$ Pharmacol. 2001; 420:19-26. [PubMed: 11412835]

Hammarberg C, Schulte G, Fredholm BB. Evidence for functional adenosine $\mathrm{A}_{3}$ receptors in microglia cells. J Neurochem. 2003; 86:1051-1054. [PubMed: 12887702]

Haneda M, Araki S-I, Sugimoto T, Togawa M, Koya D, Kikkawa R. Differential inhibition of mesangial MAP kinase cascade by cyclic nucleotides. Kidney Int. 1996; 50:384-391. [PubMed: 8840264]

Harish A, Hohana G, Fishman P, Arnon O, Bar-Yehuda S. A 3 adenosine receptor agonist potentiates natural killer cell activity. Int J Oncol. 2003; 23:1245-1249. [PubMed: 12964011]

Haskó G, Szabó C, Németh ZH, Kvetan V, Pastores SM, Vizi ES. Adenosine receptor agonists differentially regulate IL-10, TNF-alpha, and nitric oxide production in RAW 264.7 macrophages and in endotoxemic mice. J Immunol. 1996; 157:4634-4640. [PubMed: 8906843]

Heese K, Fiebich BL, Bauer J, Otten U. Nerve growth factor (NGF) expression in rat microglia is induced by adenosine $A_{2 a}$-receptors. Neurosci Lett. 1997; 231:83-86. [PubMed: 9291146]

Hockel M, Vaupel P. Tumor hypoxia: definitions and current clinical, biologic, and molecular aspects. J Natl Cancer Inst. 2001; 93:266-276. [PubMed: 11181773]

Hofer M, Pospísil M, Vacek A, Holá J, Znojil V, Weiterová L, Streitová D. Effects of adenosine A(3) receptor agonist on bone marrow granulocytic system in 5-fluorouracil-treated mice. Eur J Pharmacol. 2006; 538:163-167. [PubMed: 16643889] 
Hofer M, Pospísil M, Znojil V, Holá J, Vacek A, Streitová D. Adenosine A(3) receptor agonist acts as a homeostatic regulator of bone marrow hematopoiesis. Biomed Pharmacother. 2007; 61:356-359. [PubMed: 17383145]

Hopfl G, Ogunshola O, Gassmann M. HIFs and tumors: causes and consequences. Am J Physiol Regul Integr Comp Physiol. 2004; 286:R608-R623. [PubMed: 15003941]

Hoskin DW, Reynolds T, Blay J. Adenosine as a possible inhibitor of killer T-cell activation in the microenvironment of solid tumours. Int J Cancer. 1994; 59:854-855. [PubMed: 7989130]

Huang S, Apasov S, Koshiba M, Sitkovsky M. Role of $\mathrm{A}_{2 \mathrm{a}}$ extracellular adenosine receptor-mediated signaling in adenosine-mediated inhibition of T-cell activation and expansion. Blood. 1997; 90:1600-1610. [PubMed: 9269779]

Illes P, Klotz K-N, Lohse MJ. Signaling by extracellular nucleotides and nucleosides. NaunynSchmiedeberg's Arch Pharmacol. 2000; 362:295-298. [PubMed: 11111824]

Jacobson KA. Adenosine A3 receptors: novel ligands and paradoxical effects. Trends Pharmacol Sci. 1998; 19:184-191. [PubMed: 9652191]

Jenner P. Istradefylline, a novel adenosine $\mathrm{A}_{2 \mathrm{~A}}$ receptor antagonist, for the treatment of Parkinson's disease. Expert Opin Invest Drugs. 2005; 14:729-738.

Jeong LS, Kim MJ, Kim HO, Gao ZG, Kim SK, Jacobson KA, Chun MW. Design and synthesis of 3' ureidoadenosine- $5^{\prime}$-uronamides: effects of the $3^{\prime}$-ureido group on binding to the $\mathrm{A}_{3}$ adenosine receptor. Bioorg Med Chem Lett. 2004; 14:4851-4854. [PubMed: 15341938]

Jiang BH, Agani F, Passaniti A, Semenza GL. V-SRC induces expression of hypoxiainducible factor 1 (HIF-1) and transcription of genes encoding vascular endothelial growth factor and enolase 1: involvement of HIF-1 in tumor progression. Cancer Res. 1997; 57:5328-5335. [PubMed: 9393757]

Johansson B, Halldner L, Dunwiddie TV, Masino SA, Poelchen W, Giménez-Llort L, Escorihuela RM, Fernández-Teruel A, Wiesenfeld-Hallin Z, Xu XJ, Hårdemark A, Betsholtz C, Herlenius E, Fredholm BB. Hyperalgesia, anxiety, and decreased hypoxic neuroprotection in mice lacking the adenosine $A_{1}$ receptor. Proc Natl Acad Sci USA. 2001; 98:9407-9412. [PubMed: 11470917]

Johnston JB, Silva C, Gonzalez G, Holden J, Warren KG, Metz LM, Power C. Diminished adenosine $\mathrm{A}_{1}$ receptor expression on macrophages in brain and blood of patients with multiple sclerosis. Ann Neurol. 2001; 49:650-658. [PubMed: 11357956]

Joshi BV, Jacobson KA. Purine derivatives as ligands for $\mathrm{A}_{3}$ adenosine receptors. Curr Top Med Chem. 2005; 5:1275-1295. [PubMed: 16305531]

Karin M, Ben-Neriah Y. Phosphorylation meets ubiquitination: the control of NF- $\kappa$ B activity. Annu Rev Immunol. 2000; 18:621-663. [PubMed: 10837071]

Kim SG, Ravi G, Hoffmann C, Jung YJ, Kim M, Chen A, Jacobson KA. p53-Independent induction of Fas and apoptosis in leukemic cells by an adenosine derivative, Cl-IB-MECA. Biochem Pharmacol 2002. 2002; 63:871-880.

Kim SJ, Min HY, Chung HJ, Park EJ, Hong JY, Kang YJ, Shin DH, Jeong LS, Lee SK. Inhibition of cell proliferation through cell cycle arrest and apoptosis by thio-Cl-IB-MECA, a novel A(3) adenosine receptor agonist, in human lung cancer cells. Cancer Lett. 2008; 264:309-315. [PubMed: 18321638]

Khoa ND, Montesinos MC, Reiss AB, Delano D, Awadallah N, Cronstein BN. Inflammatory cytokines regulate function and expression of adenosine $\mathrm{A}(2 \mathrm{~A})$ receptors in human monocytic THP-1 cells. J Immunol. 2001; 167:4026-4032. [PubMed: 11564822]

Kung AL, Wang S, Klco JM, Kaelin WG, Livingston DM. Suppression of tumor growth through disruption of hypoxia-inducible transcription. Nat Med. 2000; 6:1335-1340. [PubMed: 11100117]

Küst BM, Biber K, van Calker D, Gebicke-Haerter PJ. Regulation of $\mathrm{K}^{+}$channel mRNA expression by stimulation of adenosine $\mathrm{A}_{2 \mathrm{a}}$-receptors in cultured rat microglia. Glia. 1999; 25:120-130. [PubMed: 9890627]

Lanone S, Zheng T, Zhu Z, Liu W, Lee CG, Ma B, Chen Q, Homer RJ, Wang J, Rabach LA, Rabach ME, Shipley JM, Shapiro SD, Senior RM, Elias JA. Overlapping and enzyme-specific contributions of matrix metalloproteinases-9 and -12 in IL-13-induced inflammation and remodeling. J Clin Invest. 2002; 110:463-474. [PubMed: 12189240] 
Lappas CM, Rieger JM, Linden J. A2A adenosine receptor induction inhibits IFN-gamma production in murine CD4+ T-cells. J Immunol. 2005; 174:1073-1080. [PubMed: 15634932]

Le Moine O, Stordeur P, Schandené L, Marchant A, de Groote D, Goldman M, Devière J. Adenosine enhances IL-10 secretion by human monocytes. J Immunol. 1996; 156:4408-4414. [PubMed: 8666814]

Lee HT, Gallos G, Nasr SH, Emala CW. A 1 adenosine receptor activation inhibits inflammation, necrosis, and apoptosis after renal ischemia-reperfusion injury in mice. J Am Soc Nephrol. 2004a; 15:102-111. [PubMed: 14694162]

Lee HT, Xu H, Nasr SH, Schnermann J, Emala CW. A 1 adenosine receptor knockout mice exhibit increased renal injury following ischemia and reperfusion. Am J Physiol Renal Physiol. 2004b; 286:298-306.

Lee EJ, Min HY, Chung HJ, Park EJ, Shin DH, Jeong LS, Lee SK. A novel adenosine analog, thio-ClIB-MECA, induces $\mathrm{G}_{0} / \mathrm{G}_{1}$ cell cycle arrest and apoptosis in human promyelocytic leukemia HL-60 cells. Biochem Pharmacol. 2005; 70:918-924. [PubMed: 16051194]

Li ZW, Chu W, Hu Y, Delhase M, Deerinck T, Ellisman M, Johnson R, Karin M. The IKKbeta subunit of IkappaB kinase (IKK) is essential for nuclear factor kappaB activation and prevention of apoptosis. J Exp Med. 1999; 189:1839-1845. [PubMed: 10359587]

Liao Y, Takashima S, Asano Y, Asakura M, Ogai A, Shintani Y, Minamino T, Asanuma H, Sanada S, Kim J, Ogita H, Tomoike H, Hori M, Kitakaze M. Activation of adenosine $\mathrm{A}_{1}$ receptor attenuates cardiac hypertrophy and prevents heart failure in murine left ventricular pressure-overload model. Circ Res. 2003; 93:759-766. [PubMed: 12970111]

Linden J. Molecular approach to adenosine receptors: receptor-mediated mechanisms of tissue protection. Annu Rev Pharmacol Toxicol. 2001; 41:775-787. [PubMed: 11264476]

Linden J, Thai T, Figler H, Jin X, Robeva AS. Characterization of human $A_{2 B}$ adenosine receptors: radioligand binding, western blotting, and coupling to $\mathrm{Gq}$ in human embryonic kidney 293 cells and HMC-1 mast cells. Mol Pharmacol. 1999; 56:705-713. [PubMed: 10496952]

Lu J, Pierron A, Ravid K. An adenosine analogue, IB-MECA, down-regulates estrogen receptor alpha and suppresses human breast cancer cell proliferation. Cancer Res. 2003; 63:6413-6423. [PubMed: 14559831]

Lukashev D, Ohta A, Sitkovsky M. Hypoxia-dependent anti-inflammatory pathways in protection of cancerous tissues. Cancer Metastasis Rev. 2007; 26:273-279. [PubMed: 17404693]

Mabjeesh NJ, Escuin D, LaVallee TM, Pribluda VS, Swartz GM, Johnson MS, Willard MT, Zhong H, Simons JW, Giannakakou P. 2ME2 inhibits tumor growth and angiogenesis by disrupting microtubules and dysregulating HIF. Cancer Cell. 2003; 3:363-375. [PubMed: 12726862]

MacDonald RL, Skerritt JH, Werz MA. Adenosine agonists reduce voltage-dependent calcium conductance of mouse sensory neurones in cell culture. J Physiol. 1986; 370:75-90. [PubMed: 2420981]

MacKenzie WM, Hoskin DW, Blay J. Adenosine inhibits the adhesion of anti-CD3-activated killer lymphocytes to adenocarcinoma cells through an $\mathrm{A}_{3}$ receptor. Cancer Res. 1994; 54:3521-3516. [PubMed: 8012976]

Madi L, Bar-Yehuda S, Barer F, Ardon E, Ochaion A, Fishman P. A3 adenosine receptor activation in melanoma cells: association between receptor fate and tumor growth inhibition. J Biol Chem. 2003; 278:42121-42130. [PubMed: 12865431]

Madi L, Ochaion A, Rath-Wolfson L, Bar-Yehuda S, Erlanger A, Ohana G, Harish A, Merimski O, Barer F, Fishman $\mathrm{P}$. The $\mathrm{A}_{3}$ adenosine receptor is highly expressed in tumor versus normal cells: potential target for tumor growth inhibition. Clin Cancer Res. 2004; 10:4472-4479. [PubMed: 15240539]

Markovic DS, Glass R, Synowitz M, Rooijen N, Kettenmann H. Microglia stimulate the invasiveness of glioma cells by increasing the activity of metalloprotease-2. J Neuropathol Exp Neurol. 2005; 64:754-762. [PubMed: 16141784]

Maxwell PH, Dachs GU, Gleadle JM, Nicholls LG, Harris AL, Stratford IJ, Hankinson O, Pugh CW, Ratcliffe PJ. Hypoxia-inducible factor-1 modulates gene expression in solid tumors and influences both angiogenesis and tumor growth. Proc Natl Acad Sci USA. 1997; 94:8104-8109. [PubMed: 9223322] 
Merighi S, Varani K, Gessi S, Cattabriga E, Iannotta V, Ulouglu C, Leung E, Borea PA. Pharmacological and biochemical characterization of adenosine receptors in the human malignant melanoma A375 cell line. Br J Pharmacol. 2001; 134:1215-1226. [PubMed: 11704641]

Merighi S, Mirandola P, Milani D, Varani K, Gessi S, Klotz KN, Leung E, Baraldi PG, Borea PA. Adenosine receptors as mediators of both cell proliferation and cell death of cultured human melanoma cells. J Invest Dermatol. 2002; 119:923-933. [PubMed: 12406340]

Merighi S, Mirandola P, Varani K, Gessi S, Leung E, Baraldi PG, Tabrizi MA, Borea PA. A glance at adenosine receptors: novel target for antitumor therapy. Pharmacol Ther. 2003; 100:31-48. [PubMed: 14550503]

Merighi S, Benini A, Mirandola P, Gessi S, Varani K, Leung E, Maclennan S, Borea PA. A3 adenosine receptor activation inhibits cell proliferation via phosphatidylinositol 3-kinase/Aktdependent inhibition of the extracellular signal-regulated kinase 1/2 phosphorylation in A375 human melanoma cells. J Biol Chem. 2005a; 280:19516-19526. [PubMed: 15774470]

Merighi S, Benini A, Mirandola P, Gessi S, Varani K, Leung E, MacLennan S, Baraldi PG, Borea PA. $\mathrm{A}_{3}$ adenosine receptors modulate hypoxia-inducible factor-1alpha expression in human A375 melanoma cells. Neoplasia. 2005b; 7:894-903. [PubMed: 16242072]

Merighi S, Benini A, Mirandola P, Gessi S, Varani K, Leung E, Maclennan S, Borea PA. Adenosine modulates vascular endothelial growth factor expression via hypoxia-inducible factor-1 in human glioblastoma cells. Biochem Pharmacol. 2006; 72:19-31. [PubMed: 16682012]

Merighi S, Benini A, Mirandola P, Gessi S, Varani K, Simioni C, Leung E, Maclennan S, Borea PA. Caffeine inhibits adenosine-induced accumulation of hypoxia-inducible factor-1a, vascular endothelial growth factor and interleukin- 8 expression in hypoxic human colon cancer cells. Mol Pharmacol. 2007; 72:395-406. [PubMed: 17488804]

Merimsky O, Madi L, Bar-Yehuda S, Fishman P. Modulation of the $\mathrm{A}_{3}$ adenosine receptor by low agonist concentration induced anti-tumor and myelostimulation effects. Drug Dev Res. 2003; 58:386-389.

Merrill JT, Shen C, Schreibman D, Coffey D, Zakharenko O, Fisher R, Lahita RG, Salmon J, Cronstein $\mathrm{BN}$. Adenosine $\mathrm{A}_{1}$ receptor promotion of multinucleated giant cell formation by human monocytes: a mechanism for methotrexate-induced nodulosis in rheumatoid arthritis. Arthritis Rheum. 1997; 40:1308-1315. [PubMed: 9214432]

Minchenko A, Leshchinsky I, Opentanova I, Sang N, Srinivas V, Armstead V, Caro J. Hypoxiainducible factor-1-mediated expression of the 6-phosphofructo-2-kinase/fructose-2,6bisphosphatase-3 (PFKFB3) gene. Its possible role in the Warburg effect. J Biol Chem. 2002; 277:6183-6187. [PubMed: 11744734]

Mirabet M, Mallol J, Lluis C, Franco R. Calcium mobilization in Jurkat cells via $A_{2 b}$ adenosine receptors. Br J Pharmacol. 1997; 122:1075-1082. [PubMed: 9401772]

Morello S, Petrella A, Festa M, Popolo A, Monaco M, Vuttariello E, Chiappetta G, Parente L, Pinto A. Cl-IB-MECA inhibits human thyroid cancer cell proliferation independently of $\mathrm{A}_{3}$ adenosine receptor activation. Cancer Biol Ther. 2007; 7:278-284. [PubMed: 18059189]

Morin PJ. Beta-catenin signaling and cancer. Bioessays. 1999; 21:1021-1030. [PubMed: 10580987]

Muller CE. Medicinal chemistry of adenosine A 3 receptor ligands. Curr Top Med Chem. 2003; 3:445462. [PubMed: 12570761]

Murthy KS, Makhlouf GM. Adenosine $\mathrm{A}_{1}$ receptor-mediated activation of phospholipase C-beta 3 in intestinal muscle: dual requirement for alpha and beta gamma subunits of Gi3. Mol Pharmacol. 1995; 47:1172-1179. [PubMed: 7603457]

Naganuma M, Wiznerowicz EB, Lappas CM, Linden J, Worthington MT, Ernst PB. Cutting edge: critical role for $\mathrm{A}_{2 \mathrm{~A}}$ adenosine receptors in the T cell-mediated regulation of colitis. J Immunol. 2006; 177:2765-2769. [PubMed: 16920910]

Nakamura K, Yoshikawa N, Yamaguchi Y, Kagota S, Shinozuka K, Kunitomo M. Antitumor effect of cordycepin ( 3 '-deoxyadenosine) on mouse melanoma and lung carcinoma cells involves adenosine $\mathrm{A}_{3}$ receptor stimulation. Anticancer Res. 2006; 26:43-47. [PubMed: 16475677]

Novak A, Dedhar S. Signaling through beta-catenin and Lef/Tcf. Cell Mol Life Sci. 1999; 56:523-537. [PubMed: 11212302] 
Ogata T, Schubert P. Programmed cell death in rat microglia is controlled by extracellular adenosine. Neurosci Lett. 1996; 218:91-94. [PubMed: 8945735]

Ohana G, Bar-Yehuda S, Arich A, Madi L, Dreznick Z, Silberman D, Slosman G, Volfsson-Rath L, Fishman Pnina. Inhibition of primary colon carcinoma growth and liver metastasis by the A3 adenosine receptor agonist CF101. Br J Cancer. 2003; 89:1552-1558. [PubMed: 14562031]

Ohta A, Sitkovsky M. Role of G-protein-coupled adenosine receptors in downregulation of inflammation and protection from tissue damage. Nature. 2001; 414:916-920. [PubMed: 11780065]

Ohta A, Gorelik E, Prasad SJ, Ronchese F, Lukashev D, Wong MK, Huang X, Caldwell S, Liu K, Smith P, Chen JF, Jackson EK, Apasov S, Abrams S, Sitkovsky M. A 2 A adenosine receptor protects tumors from antitumor T-cells. Proc Natl Acad Sci USA. 2006; 103:13132-13137. [PubMed: 16916931]

Olah ME, Stiles GL. Adenosine receptor subtypes: characterization and therapeutic regulation. Annu Rev Pharmacol Toxicol. 1995; 35:581-606. [PubMed: 7598508]

Olah ME, Ren H, Stiles GL. Adenosine receptors: protein and gene structure. Arch Pharmacodyn. 1995; 329:135-150.

Overwijk WW, Restifo NP. Creating therapeutic cancer vaccines: notes from the battlefield. Trends Immunol. 2001; 22:5-7. [PubMed: 11286676]

Panjehpour M, Karami-Tehrani F. An adenosine analog (IB-MECA) inhibits anchorage-dependent cell growth of various human breast cancer cell lines. Int J Biochem Cell Biol. 2004; 36:1502-1509. [PubMed: 15147729]

Panjehpour M, Karami-Tehrani F. Adenosine modulates cell growth in the human breast cancer cells via adenosine receptors. Oncol Res. 2007; 16:575-585. [PubMed: 18351132]

Panjehpour M, Castro M, Klotz K-N. Human breast cancer cell line MDA-MB-231 expresses endogenous $\mathrm{A}_{2 \mathrm{~B}}$ adenosine receptors mediating a $\mathrm{Ca}^{2+}$ signal. Br J Pharmacol. 2005; 145:211218. [PubMed: 15753948]

Panther E, Idzko M, Herouy Y, Rheinen H, Gebicke-Haerter PJ, Mrowietz U, Dichmann S, Norgauer J. Expression and function of adenosine receptors in human dendritic cells. FASEB J. 2001; 15:1963-1970. [PubMed: 11532976]

Pardoll DM. Spinning molecular immunology into successful immunotherapy. Nat Rev Immunol. 2002; 2:227-238. [PubMed: 12001994]

Peifer M, Polakis P. Wnt signaling in oncogenesis and embryogenesis: a look outside the nucleus. Science. 2000; 287:1606-1609. [PubMed: 10733430]

Plesner L. Ecto-ATPases: identities and functions. Int Rev Cytol. 1995; 158:141-214. [PubMed: 7721538]

Poulsen SA, Quinn RJ. Adenosine receptors: new opportunities for future drugs. Bioorg Med Chem. 1998; 6:619-641. [PubMed: 9681130]

Prinz M, Hanisch UK. Murine microglial cells produce and respond to interleukin-18. J Neurochem. 1999; 72:2215-2218. [PubMed: 10217305]

Raman M, Chen W, Cobb MH. Differential regulation and properties of MAPKs. Oncogene. 2007; 26:3100-3112. [PubMed: 17496909]

Rao JS. Molecular mechanisms of glioma invasiveness: the role of proteases. Nat Rev Cancer. 2003; 3:489-501. [PubMed: 12835669]

Raskovalova T, Lokshin A, Huang X, Jackson EK, Gorelik E. Adenosine-mediated inhibition of cytotoxic activity and cytokine production by IL-2/NKp46-activated NK cells: involvement of protein kinase A isozyme I (PKA I). Immunol Res. 2006; 36:91-99. [PubMed: 17337770]

Raskovalova T, Lokshin A, Huang X, Su Y, Mandic M, Zarour HM, Jackson EK, Gorelik E. Inhibition of cytokine production and cytotoxic activity of human antimelanoma specific CD8+ and CD4+ T lymphocytes by adenosine-protein kinase A type I signaling. Cancer Res. 2007; 67:5949-5956. [PubMed: 17575165]

Ratcliffe PJ, Pugh CW, Maxwell PH. Targeting tumors through the HIF system. Nat Med. 2000; 6:1315-1316. [PubMed: 11100107] 
Robbins PF, El-Gamil M, Li YF, Kawakami Y, Loftus D, Appella E, Rosenberg SA. A mutated betacatenin gene encodes a melanoma-specific antigen recognized by tumor infiltrating lymphocytes. J Exp Med. 1996; 183:1185-1192. [PubMed: 8642260]

Rusthoven J, Bramwell V, Stephenson B. Use of granulocyte colony-stimulating factor (G-CSF) in patients receiving myelosuppressive chemotherapy for the treatment of cancer. Provincial systemic treatment disease site group. Cancer Prev Control. 1998; 2:179-190. [PubMed: 10093631]

Sajjadi FG, Firestein GS. cDNA cloning and sequence analysis of the human $\mathrm{A}_{3}$ adenosine receptor. Biochim Biophys Acta. 1993; 1179:105-107. [PubMed: 8399349]

Sajjadi FG, Takabayashi K, Foster AC, Domingo RC, Firestein GS. Inhibition of TNF-alpha expression by adenosine: role of $A_{3}$ adenosine receptors. J Immunol. 1996; 156:3435-3442. [PubMed: 8617970]

Salmon JE, Cronstein BN. Fc gamma receptor-mediated functions in neutrophils are modulated by adenosine receptor occupancy. $\mathrm{A}_{1}$ receptors are stimulatory and $\mathrm{A}_{2}$ receptors are inhibitory. $\mathrm{J}$ Immunol. 1990; 145:2235-2240. [PubMed: 2168919]

Salmon JE, Brogle N, Brownlie C, Edberg JC, Kimberly RP, Chen BX, Erlanger BF. Human mononuclear phagocytes express adenosine $\mathrm{A}_{1}$ receptors. A novel mechanism for differential regulation of Fc gamma receptor function. J Immunol. 1993; 151:2775-2785. [PubMed: 8360491]

Salvatore CA, Jacobson MA, Taylor HE, Linden J, Johnson RG. Molecular cloning an characterization of the human $A_{3}$ adenosine receptor. Proc Natl Acad Sci USA. 1993; 90:10365-10369. [PubMed: 8234299]

Scheibner KA, Lutz MA, Boodoo S, Fenton MJ, Powell JD, Horton MR. Hyaluronan fragments act as an endogenous danger signal by engaging TLR2. J Immunol. 2006; 177:1272-1281. [PubMed: 16818787]

Schnitzer J. Enzyme-histochemical demonstration of microglial cells in the adult and postnatal rabbit retina. J Comp Neurol. 1989; 282:249-263. [PubMed: 2540228]

Schnurr M, Toy T, Shin A, Hartmann G, Rothenfusser S, Soellner J, Davis ID, Cebon J, Maraskovsky E. Role of adenosine receptors in regulating chemotaxis and cytokine production of plasmacytoid dendritic cells. Blood. 2004; 103:1391-1397. [PubMed: 14551144]

Schoen SW, Graeber MB, Kreutzberg GW. 5' -Nucleotidase immunoreactivity of perineuronal microglia responding to rat facial nerve axotomy. Glia. 1992; 6:314-317. [PubMed: 1464463]

Schulte G, Fredholm BB. Human adenosine $A_{1}, A_{2 A}, A_{2 B}$, and $A_{3}$ receptors expressed in Chinese hamster ovary cells all mediate the phosphorylation of extracellular-regulated kinase $1 / 2$. Mol Pharmacol. 2000; 58:477-482. [PubMed: 10953039]

Seino S, Shibasaki T. PKA-dependent and PKA-independent pathways for cAMP-regulated exocytosis. Physiol Rev. 2005; 85:1303-1342. [PubMed: 16183914]

Semenza GL. HIF-1: mediator of physiological and pathophysiological responses to hypoxia. J Appl Physiol. 2000; 88:1474-1480. [PubMed: 10749844]

Semenza GL. Signal transduction to hypoxia-inducible factor 1. Biochem Pharmacol. 2002; 64:993998. [PubMed: 12213597]

Semenza GL. Targeting HIF-1 for cancer therapy. Nat Rev Cancer. 2003; 3:721-732. [PubMed: 13130303]

Sevigny CP, Li L, Awad AS, Huang L, McDuffie M, Linden J, Lobo PI, Okusa MD. Activation of adenosine $2 \mathrm{~A}$ receptors attenuates allograft rejection and alloantigen recognition. J Immunol. 2007; 178:4240-4249. [PubMed: 17371980]

Shi Y, Evans JE, Rock KL. Molecular identification of a danger signal that alerts the immune system to dying cells. Nature. 2003; 425:516-521. [PubMed: 14520412]

Si QS, Nakamura Y, Schubert P, Rudolphi K, Kataoka K. Adenosine and propentofylline inhibit the proliferation of cultured microglial cells. Exp Neurol. 1996; 137:345-349. [PubMed: 8635550]

Sitkovsky MV, Ohta A. The 'danger' sensors that STOP the immune response: the $\mathrm{A}_{2}$ adenosine receptors? Trends Immunol. 2005; 26:299-304. [PubMed: 15922945]

Sitkovsky MV, Lukashev D, Apasov S, Kojima H, Koshiba M, Caldwell C, Ohta A, Thiel M. Physiological control of immune response and inflammatory tissue damage by hypoxiainducible 
factors and adenosine $A_{2 A}$ receptors. Annu Rev Immunol. 2004; 22:657-682. [PubMed: 15032592]

Spychala J, Lazarowski E, Ostapkowiecz A, Ayscue LH, Jin A, Mitchell BS. Role of estrogen receptor in the regulation of ecto- $5^{\prime}$-nucleotidase and adenosine in breast cancer. Clin Cancer Res. 2004; 10:708-717. [PubMed: 14760094]

Suh BC, Kim TD, Lee JU, Seong JK, Kim KT. Pharmacological characterization of adeno-sine receptors in PGT-beta mouse pineal gland tumour cells. Br J Pharmacol. 2001; 134:132-142. [PubMed: 11522605]

Sullivan $\mathrm{GW}$. Adenosine $\mathrm{A}_{2 \mathrm{~A}}$ receptor agonists as anti-inflammatory agents. Curr Opin Invest Drugs. 2003; 4:1313-1319.

Sun CX, Young HW, Molina JG, Volmer JB, Schnermann J, Blackburn MR. A protective role for the $\mathrm{A}_{1}$ adenosine receptor in adenosine-dependent pulmonary injury. J Clin Invest. 2005; 115:35-43. [PubMed: 15630442]

Synowitz M, Glass R, Fäarber K, Markovic D, Kronenberg G, Herrmann K, Schnermann J, Nolte C, van Rooijen N, Kiwit J, Kettenmann H. A 1 adenosine receptors in microglia control glioblastoma-host interaction. Cancer Res. 2006; 66:8550-8557. [PubMed: 16951167]

Trincavelli ML, Tuscano D, Marroni M, Falleni A, Gremigni V, Ceruti S, Abbracchio MP, Jacobson KA, Cattabeni F, Martini C. $\mathrm{A}_{3}$ adenosine receptors in human astrocytoma cells: agonistmediated desensitization, internalization, and down-regulation. Mol Pharmacol. 2002; 62:13731384. [PubMed: 12435805]

Trussell LO, Jackson MB. Adenosine-activated potassium conductance in cultured striatal neurons. Proc Natl Acad Sci USA. 1985; 82:4857-4861. [PubMed: 2991897]

Tsutsui S, Schnermann J, Noorbakhsh F, Henry S, Yong VW, Winston BW, Warren K, Power C. A 1 adenosine receptor upregulation and activation attenuates neuroinflammation and demyelination in a model of multiple sclerosis. J Neurosci. 2004; 24:1521-1529. [PubMed: 14960625]

van Troostenburg AR, Clark EV, Carey WDH, Warrington SJ, Kerns WD, Cohn I, Silverman MH, Bar-Yehuda S, Fong KLL, Fishman P. Tolerability, pharmacokinetics, and concentrationdependent hemodynamic effects of oral CF101, an $\mathrm{A}_{3}$ adenosine receptor agonist, in healthy young men. Int J Clin Pharmacol Ther. 2004; 42:534-542. [PubMed: 15516022]

Volpini R, Costanzi S, Vittori S, Cristalli G, Klotz KN. Medicinal chemistry and pharmacology of $\mathrm{A}_{2 \mathrm{~B}}$ adenosine receptors. Curr Top Med Chem. 2003; 3:427-443. [PubMed: 12570760]

Welsh SJ, Powis G. Hypoxia inducible factor as a cancer drug target. Curr Cancer Drug Targets. 2003; 3:391-405. [PubMed: 14683498]

Werb Z, Gordon S. Elastase secretion by stimulated macrophages. Characterization and regulation. J Exp Med. 1975; 142:361-377. [PubMed: 167096]

Wiener CM, Booth G, Semenza GL. In vivo expression of mRNAs encoding hypoxiainducible factor 1. Biochem Biophys Res Commun. 1996; 225:485-488. [PubMed: 8753788]

Williams JH, Ireland HE. Sensing danger-Hsp72 and HMGB1 as candidate signals. J Leukoc Biol. 2008; 83:489-492. [PubMed: 18156188]

Williams BA, Manzer A, Blay J, Hoskin DW. Adenosine acts through a novel extracellular receptor to inhibit granule exocytosis by natural killer cells. Biochem Biophys Res Commun. 1997; 231:264-269. [PubMed: 9070261]

Xu Z, Jang Y, Mueller RA, Norfleet EA. IB-MECA and cardioprotection. Cardiovasc Drug Rev. 2006; 24:227-238. [PubMed: 17214599]

Yao Y, Sei Y, Abbracchio MP, Jiang JL, Kim YC, Jacobson KA. Adenosine A 3 receptor agonists protect HL-60 and U-937 cells from apoptosis induced by $\mathrm{A}_{3}$ antagonists. Biochem Biophys Res Commun. 1997; 232:317-322. [PubMed: 9125172]

Zablocki JA, Wu L, Shryock J, Belardinelli L. Partial A(1) adenosine receptor agonists from a molecular perspective and their potential use as chronic ventricular rate control agents during atrial fibrillation (AF). Curr Top Med Chem. 2004; 4:839-854. [PubMed: 15078215]

Zarek PE, Huang CT, Lutz ER, Kowalski J, Horton MR, Linden J, Drake CG, Powell JD. A2A receptor signaling promotes peripheral tolerance by inducing T-cell anergy and the generation of adaptive regulatory T-cells. Blood. 2008; 111:251-259. [PubMed: 17909080] 
Zeng D, Maa T, Wang U, Feoktistov I, Biaggioni I, Belardinelli L. Expression and function of $\mathrm{A}_{2}$ adenosine receptors in the U87MG tumor cells. Drug Dev Res. 2003; 58:405-411.

Zhao Z, Makaritsis K, Francis CE, Gavras H, Ravid K. A role for the $\mathrm{A}_{3}$ adenosine receptor in determining tissue levels of cAMP and blood pressure: studies in knock-out mice. Biochim Biophys Acta. 2000; 1500:280-290. [PubMed: 10699369]

Zhong H, De Marzo AM, Laughner E, Lim M, Hilton DA, Zagzag D, Buechler P, Isaacs WB, Semenza GL, Simons JW. Overexpression of hypoxia-inducible factor 1alpha in common human cancers and their metastases. Cancer Res. 1999; 59:5830-5835. [PubMed: 10582706]

Zhong H, Chiles K, Feldser D, Laughner E, Hanrahan C, Georgescu MM, Simons JW, Semenza GL. Modulation of hypoxia-inducible factor 1alpha expression by the epidermal growth factor/ phosphatidylinositol 3-kinase/PTEN/AKT/FRAP pathway in human prostate cancer cells: implications for tumor angiogenesis and therapeutics. Cancer Res. 2000; 60:1541-1545. [PubMed: 10749120] 


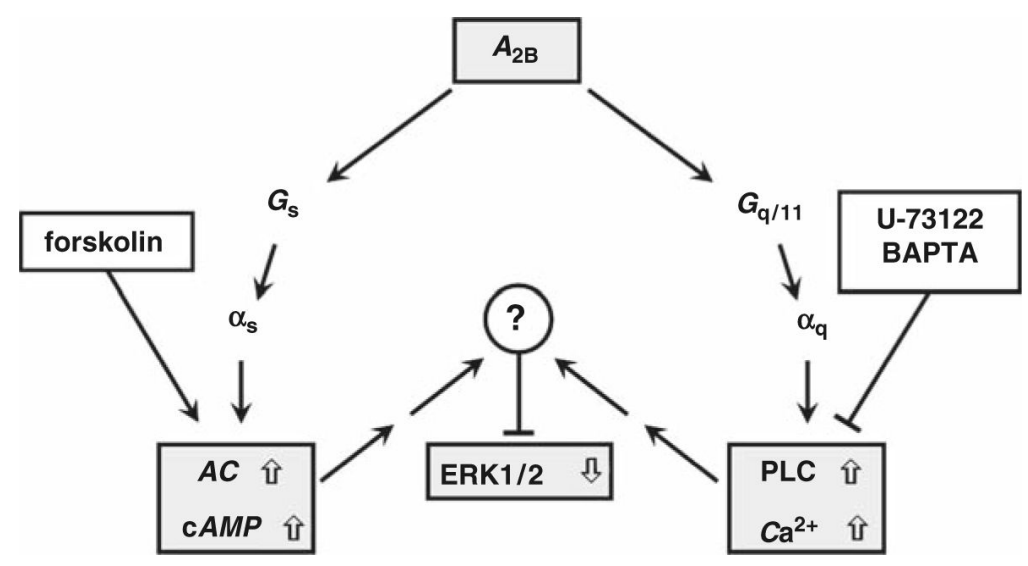

Fig. 1.

Possible pathways leading to inhibition of extracellular signal regulated kinase (ERK)1/2 phosphorylation by $\mathrm{A}_{2 \mathrm{~B}}$ adenosine receptors $\left(\mathrm{A}_{2 \mathrm{~B}} \mathrm{ARs}\right)$. Stimulation of adenylate cyclase (AC) via the $\mathrm{G}_{\mathrm{s}}$ pathway results in inhibition of mitogen-activated protein kinase (MAPK) activity. Forskolin mimics this inhibition, confirming a role of cAMP. Alternatively, $\mathrm{G}_{\mathrm{q} / 11}$ may be activated by $\mathrm{A}_{2 \mathrm{~B}} \mathrm{AR}$ stimulation, resulting in an increased activity of phospholipase $\mathrm{C}$ (PLC) and in intracellular $\mathrm{Ca}^{2+}$ signal. The PLC inhibitor U-73122 and the $\mathrm{Ca}^{2+}$ chelator BAPTA (applied as the cell-penetrating ester BAPTA-AM) both abolish $\mathrm{A}_{2 \mathrm{~B}} \mathrm{AR}$-mediated inhibition of MAPK, providing evidence for a second pathway leading to the inhibition of ERK $1 / 2$ phosphorylation. Both the $\mathrm{G}_{\mathrm{s}}$ - and the $\mathrm{G}_{\mathrm{q} / 11}$-mediated signals are linked to MAPK inhibition via currently unknown pathways 


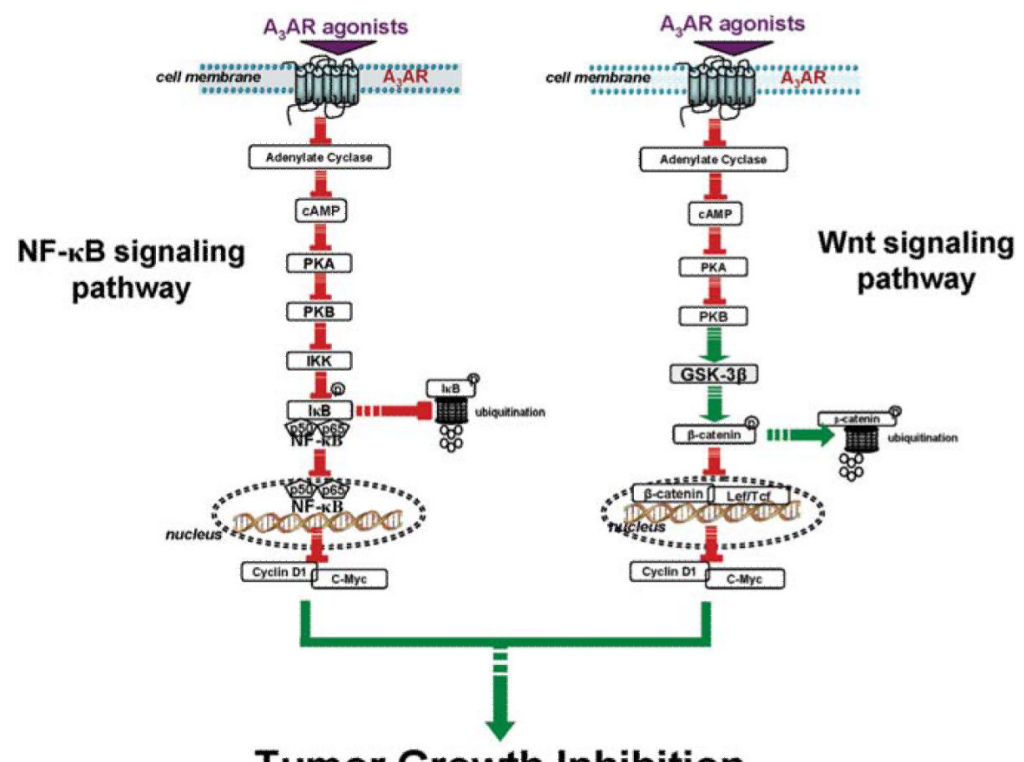

Tumor Growth Inhibition

Fig. 2.

Anticancer effect of $\mathrm{A}_{3}$ adenosine receptor $\left(\mathrm{A}_{3} \mathrm{AR}\right)$ agonists entails deregulation of the nuclear factor kappa $B(N F-\kappa B)$ and the Wnt signaling pathways. Activation of the $\mathrm{A}_{3} \mathrm{AR}$ in tumor cells with specific agonists inhibits the activity of adenylate cyclase, inducing a decline in the level of cAMP, leading to decreased levels of protein kinase A (PKA) and its substrate protein kinase B (PKB)/Akt. Consequently, this leads to a downregulation in the expression levels of signal proteins that play a role in the NF- $\kappa$ B (I $\kappa B$ kinase (IKK) and

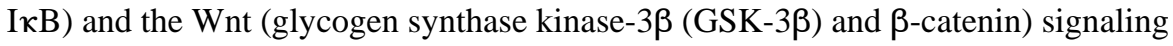
pathways. As a result, the levels of $c$-Myc and cyclin D1, known to play a crucial role in cell cycle progression, are decreased. This chain of events leads to tumor growth inhibition 


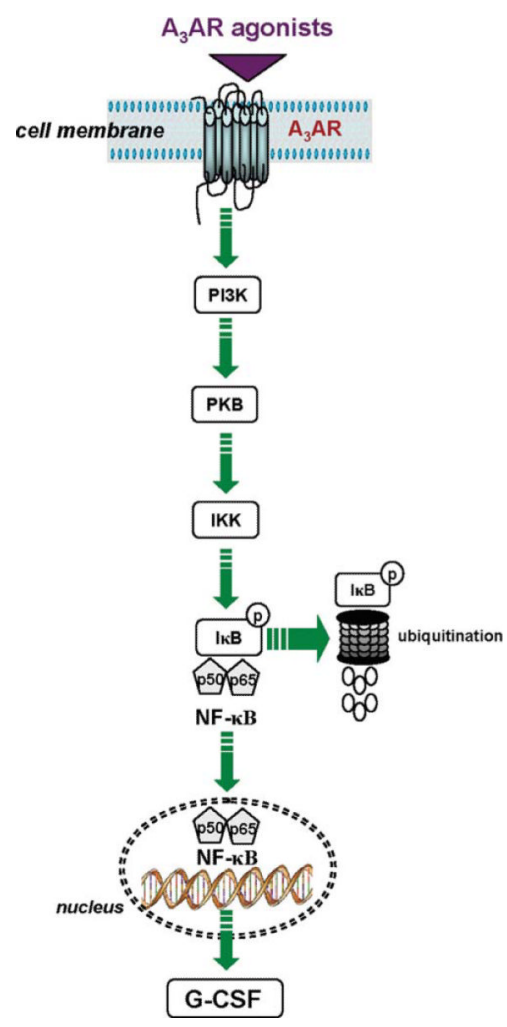

Fig. 3.

Agonists for the $\mathrm{A}_{3}$ adenosine receptor $\left(\mathrm{A}_{3} \mathrm{AR}\right)$ induce granulocyte colony stimulating factor $(\mathrm{G}-\mathrm{CSF})$ production via nuclear factor kappa $\mathrm{B}(\mathrm{NF}-\kappa \mathrm{B})$. Activation of $\mathrm{A}_{3} \mathrm{AR}$ in splenocytes induces upregulation of phosphoinositide 3-kinases (PI3K) and its downstream target protein kinase B (PKB)/Akt. The latter activates I $\kappa \mathrm{B}$ kinase (IKK), which is responsible for the phosphorylation and ubiquitination of $\mathrm{I} \kappa \mathrm{B}$. As a result, NF- $\kappa \mathrm{B}$ translocates to the nucleus, where it induces the transcription of G-CSF 


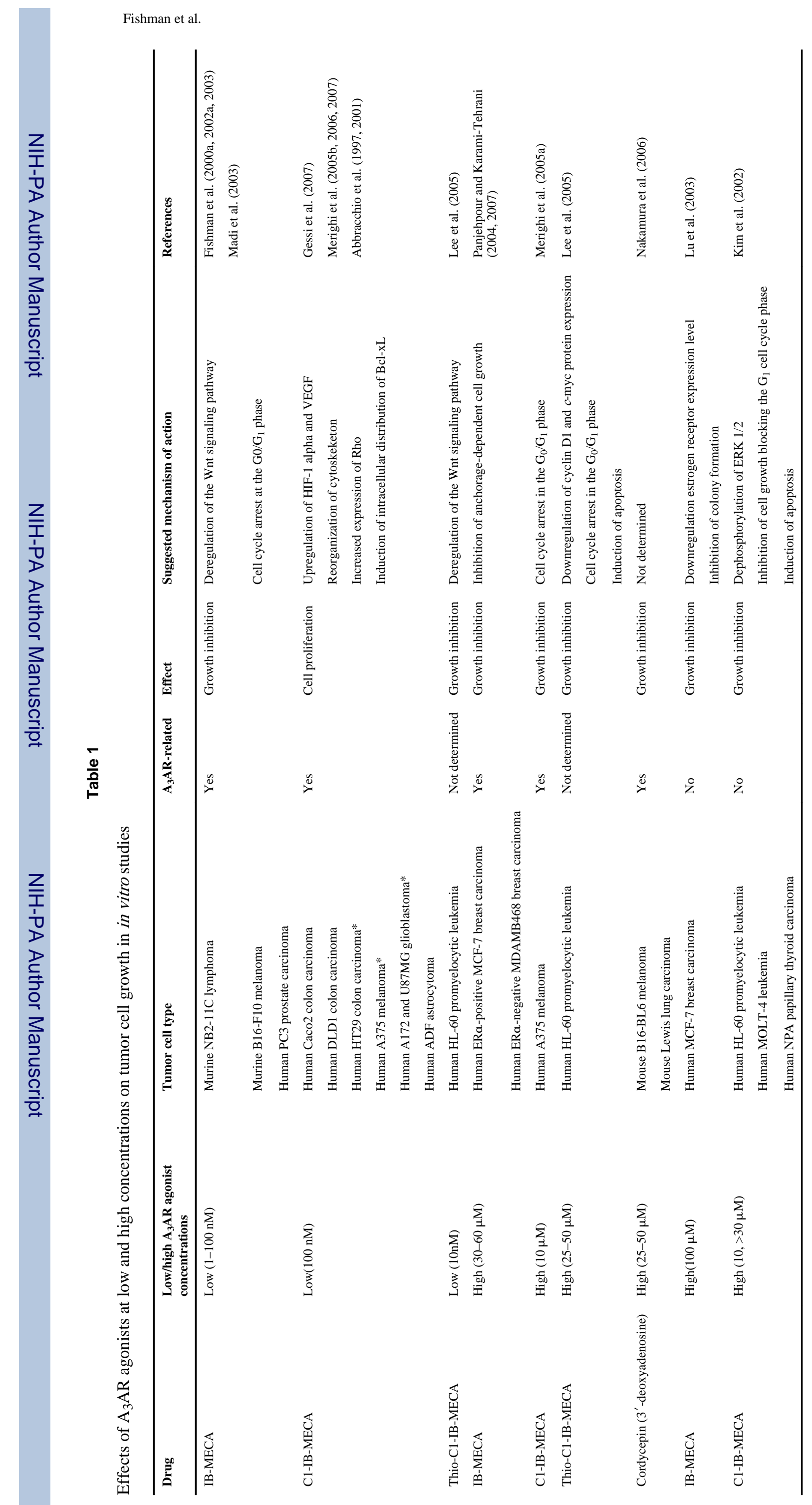

Page 37 